\title{
Crops, weeds and gathered plants in the vicinity of the mediaeval Castle Kolno, near Brzeg, S-W Poland, and a morphometric approach for some taxa
}

\author{
Romuald Kosina (iD) Lech Marek
}

Received: 1 August 2020/Accepted: 9 March 2021 / Published online: 18 March 2021

(C) The Author(s) 2021

\begin{abstract}
In the present work, numerous species of useful and wild plants were identified in the archaeobotanical samples (moat deposit and two ceramic jugs) collected from the mediaeval locality of the Kolno Castle, near Brzeg, south-western Poland. At the confluence of two rivers, in the vicinity of the castle, it was possible to cultivate cereals on poor alluvial soil, in the ground with a layer of ferruginous concretions. The characteristic weeds of the classes Secalinetea and Chenopodietea indicated the cultivation of winter cereals and garden plants. Polymorphic populations of millet were cultivated. Apart from the annual plants, the following fruit trees were grown: plums, peaches and walnuts. Fruits of many wild species were also gathered for consumption. Correlation analysis of the characters of Prunus L. stones proved that the development of the organ is conservative. Morphometric analysis of the plum stones showed that in addition to the specimens belonging to the species Prunus spinosa L. and Prunus domestica L./Prunus insititia L., there were hybrids between these two species. Multivariate analyses evidenced that the complexes of cultivated and wild plums and cherries
\end{abstract}

R. Kosina ( $\square)$

Institute of Environmental Biology, University of Wroclaw, Przybyszewskiego 63, 51-148 Wroclaw, Poland e-mail: romuald.kosina@uwr.edu.pl

L. Marek

Institute of Archaeology, University of Wroclaw, Szewska 48, 50-137 Wroclaw, Poland can form hybrid syngameons revealing continuous variation and non-random structure. The variability of filbert nuts corresponded to the variability of a large modern population of this species that is composed of many genetically different morphotypes. Variabilities of inter-specific units of fossil and contemporary forms belonging to various taxa were described by ellipsoids of various shapes and arrangements in the three-dimensional ordination space.

Keywords Mediaeval crops · Weeds - Intraspecific variation · Past versus present - Morphometry . Syngameons

\section{Introduction}

In the past, water from a river was used to construct a moat in any fortified settlement located nearby. The water environment of the Kolno Castle is similar to that of the Rozprza lowland settlement with a rich river net (Kittel et al. 2018). A sample of a moat deposit appeared to be an important source of archaeobotanical data (Wiethold 1995; Beneš et al. 2002; Kittel et al. 2018). However, the interpretation of results based on the analysis of such a sample is always difficult, as the origin of sediments is different. First of all, the sediment is alluvial if a moat is connected to a river flowing in the vicinity. This is just 
the case with the moat of the small settlement over the Rozprza River, Central Poland (Kittel et al. 2018). The same probably applies to the Kolno Castle discussed in this paper. The diversity of this sediment is dependent on the speed of the water flowing through or into the moat, and the speed in turn depends on the annual variation in the levels of water (low or high), including spring and summer floods. The organic material of a moat mostly contains diaspores of wild plants growing in the vicinity of the settlement. This has been well documented in the mediaeval moat of Kiel (Wiethold 1995). Secondly, the deposit is supplemented by rubbish, thrown into the moat, at least in some of its places. It is a rare case to find whole pots in a moat, that are arranged horizontally to allow depositing organic debris in them. Two jugs excavated from the moat of the Kolno Castle were found arranged horizontally. They contained plant remains that might have been deposited by a user or randomly by the water inflow. It is important to investigate this issue in order to understand the activity of the castles inhabitants.

Analysis of plant remains usually provides information about several types of plants, including the wild ones growing in the area and the crops and weeds growing on cultivated fields as well as the plants gathered from the natural vegetation. In most cases, only a small number of diaspores are available for studies. However, even on such a small sample, a researcher can perform a taxonomic morphometric analysis. A comparison of fossil taxa with modern ones can be carried out with the use of marker traits characterised by low redundancy. Such traits have been determined for the nuts of Corylus avellana L. by Kosina (1991) and for the stones of Prunus spinosa L. by Staszak (2004). Morphometric analyses are highly useful for studying the structure of fossil and modern populations, especially those of a hybrid nature (Wójcicki 1991a, b; Woldring 1997/1978; Nielsen and Orlik 2001; Pollman et al. 2005; Horvath et al. 2011). Reproductive contacts between wild and cultivated species leading to the creation of natural hybrids become more possible when natural ecosystems are converted into anthropogenic. At a later stage, wild-weedy-cultivated plant complexes often achieve the syngameon status (Grant 1981). Fossils collected from the Kolno Castle can be used for performing such a morphometric analysis, which might provide data about changes induced by the man-made environments in useful plants. Plant species interacting reproductively in syngameons differ in their hybridisation potential, and hence, the hybridisation network between them is asymmetric and non-random (Grant 1981; Boecklen 2017). Analysis of this phenomenon in the man-induced syngameons will help us in better understanding the relationships between crops and their wild ancestors.

Changes in the environment caused by man during a long history had resulted in the diversification of plants, including both wild and cultivated ones. Additionally, the latter were consciously altered by artificial selection. This was followed by gene exchange and introgression between wild and related cultivated species. At present, in the Anthropocene Era, this phenomenon is occurring at an increasing rate due to the forced migration of plants and alterations of their habitats (Cannon and Petit 2020). Undoubtedly, the environment of the Kolno Castle might have been subjected to selection pressure by both natural hydrological changes and human activity. Cannon and Petit (2020) considered two types of habitat components with different selection potential, a more sensitive aboveground and a more stable belowground. In both these components, many factors influence the variability of gene exchange. The interaction of changes occurring in both habitats (above- and belowground) increases the possibilities of interspecific gene exchange and ultimately the size of the syngameon. For instance, Grant (1963) proved for the genus Gilia Ruiz et Pavon that interspecific gene exchange, among other factors, was environmentally determined. It can be considered that in the vicinity of the Kolno Castle, hydrological changes (belowground component) in particular could cause the disappearance of some species and the migration of others. Knowledge of the status of ancient and modern syngameons will be a valuable supplement to the data on plant speciation.

\section{Materials and methods}

\section{Archaeological context}

Castle Kolno is located on a floodplain, to the south of the village of Stare Kolnie (Fig. 1, Alt Köln), Opole District, where the Budkowiczanka distributary branches off the mainstream of the Stobrawa River (coordinates: N: 5050'32', E: 1740'06" (1942 coordinate system BLH); x: 5,634,115,69; y: 6,476,520,10 


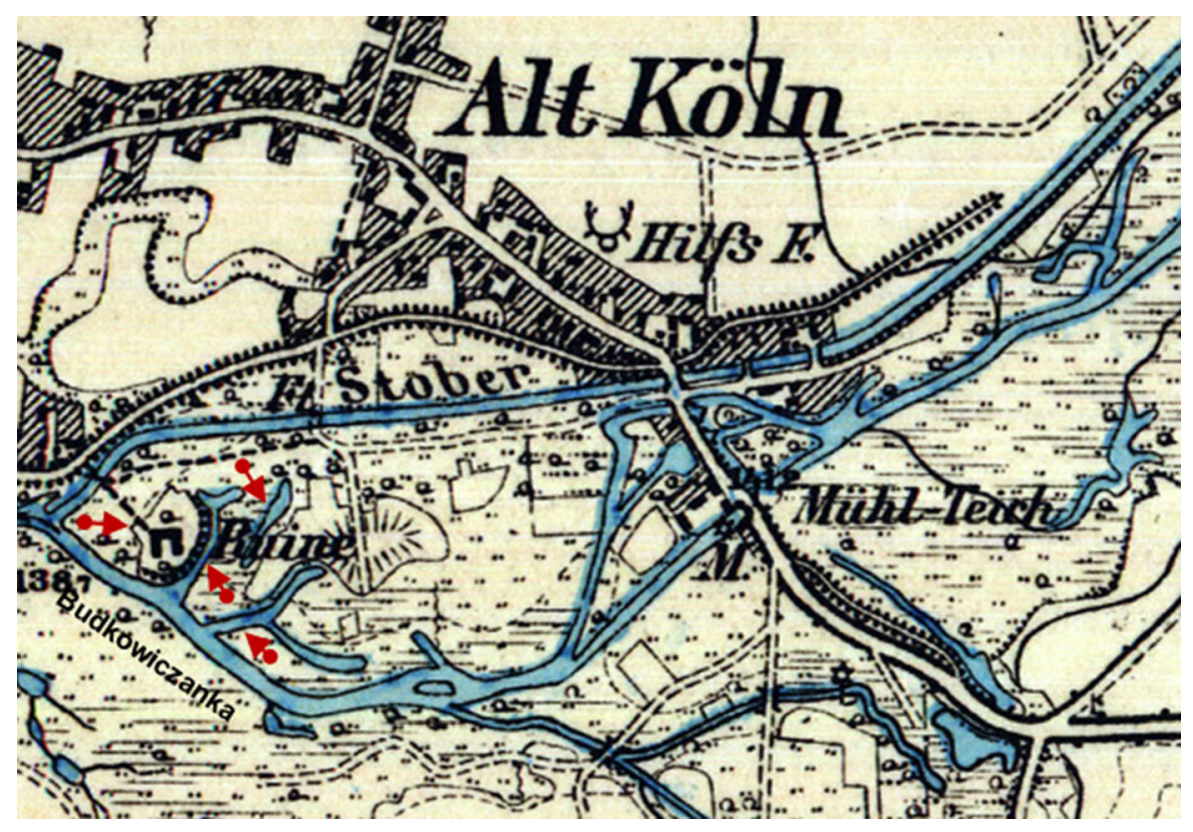

Fig. 1 A fragment of the map of Alt Poppelau issued in 1884, showing the castle of Kolno (Ruine) located between the Stobrawa (Fl. Stober) and Budkowiczanka Rivers and the village Stare Kolnie (Alt Köln). The arrow on the left marks the

(2000/6 coordinate system xyh)) (Figs. 1 and 2). Originally, the fortress guarded the border between the Duchy of Opole and the Duchy of Brzeg. It had been set a fire and put to ruin on the day of St. Margaret (July 13) in 1443 (Sommersberg 1729, p. 80: Castrum Callen ruptum fuit: Ipso die S. Margarethae \& diebus sequentibus raptum \& exustum Fuit castrum Callen prope Bregam). Further information on the history of the castle can be found in the work of Marek (2014) describing the so-called succession war in Silesia (Ermisch 1876).

The geomorphology of the site is characterised by the deposits of alluvial sand and gravel forming the terraces of the Stobrawa and Budkowiczanka Rivers. During the excavations on the site, Holocene river fans had been recorded to comprise of organic and loamy silts as well as sandy loam soil, typical of floodplains. The main castle is located on a dune formed by aeolian processes and subsequent anthropogenic alterations. The moat fill of the castle (Fig. 3c), from which the analysed samples were taken, is of natural and anthropogenic origin. It contains organic matter of plant and animal origin mixed with various archaeological artifacts dated to the period between the beginning of the fourteenth century and the castle hill, and arrows on the right point at the backwater of the Budkowiczanka River. Adapted from http://igrek.amzp.pl/ TK25_5172

destruction date of the castle in 1443. The moat fill of the castle is by no means an orderly archaeological strata sequence. It had been influenced by alluvial processes and distorted by objects falling into the water filled in the moat during its service life. An early 14th-century date has been established using dendrochronology for the beginning of this context. The dates were predicted from the relics of the timber bridge connecting the main castle to the bailey. The dendrochronological analysis was performed by Marek Krąpiec, (AGH University of Science and Technology, Cracow). All wood samples were identified as belonging to Quercus sp. The felling dates of the trees found in the moat covered the time span from 1292 to 1325 . Moreover, the precise dating of the context was proved by the earliest artifacts, such as the following: the ceramic relief effigy of a Silesian duke, most probably Bolesław III the Generous, the first owner of the castle to be recorded in the written sources (Marek 2017); a seal stamp of the early fourteenth century (Ibidem) and the Prague groschen of Wenceslaus II of Poland and Bohemia minted in 1300-1305 (unpublished find from 2018). The end of the sequence was confirmed by archaeological records based on samples from the castle's destruction layers 

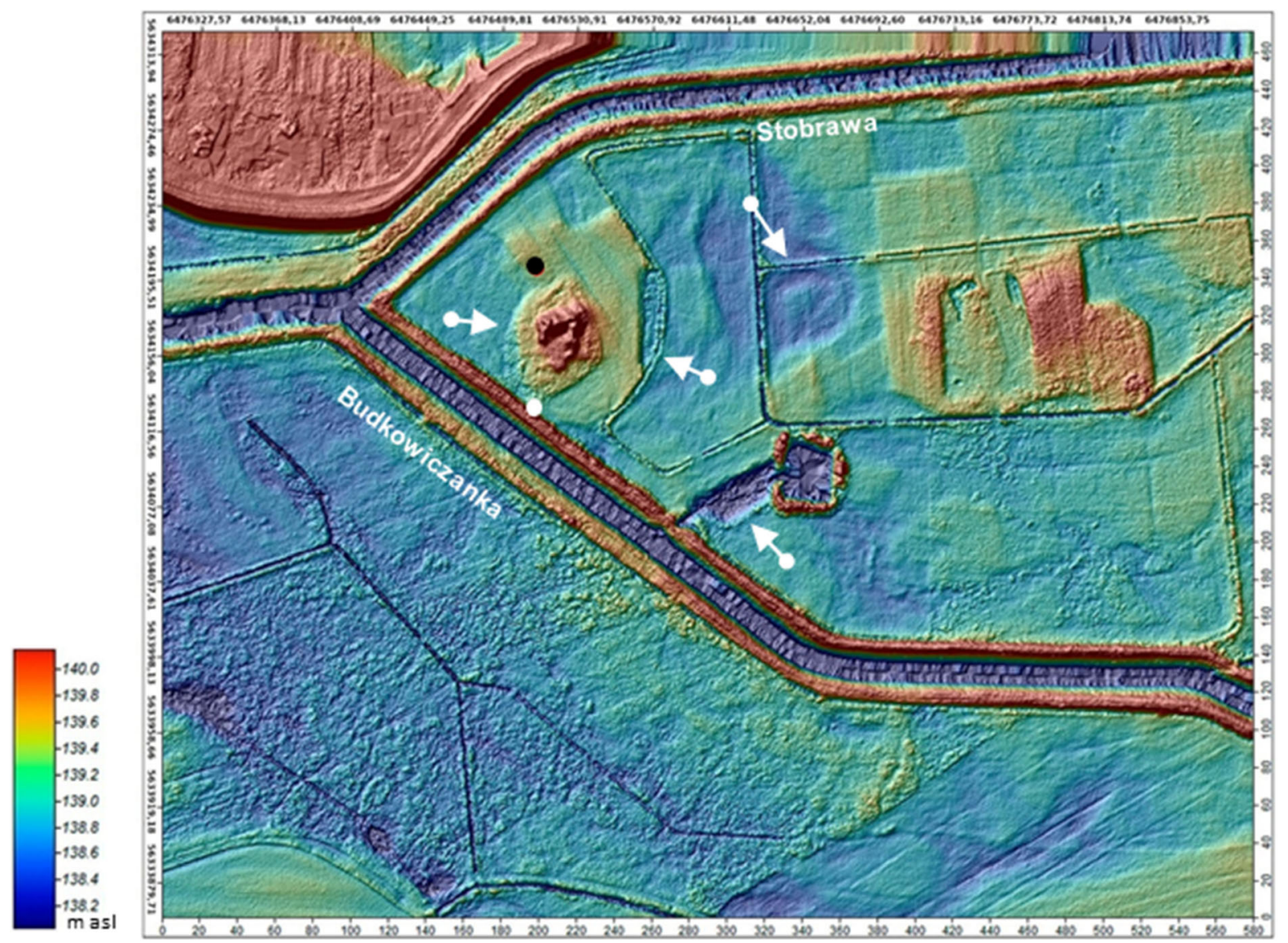

Fig. 2 Location of the archaeological excavation and mediaeval jug finds (black dot) at the site Stare Kolnie 4 (the Ducal Castle of Kolno). White arrows are shown in correlation with Fig. 1. A shrub of the putative hybrid of Prunus spinosa/P. insititia is marked by a white dot. Elevations of land indicate the

containing militaria related to the siege of 1443 and coin finds-mostly Silesian hellers (Marek and Paszkiewicz 2012). The latter were minted in the $20 \mathrm{~s}$ and 30 s of the fifteenth century, but the dates did not exceed the date of the castle's downfall.

On the basis of their technology and typology, the jugs containing plant fossils (Fig. 3D, E) could be dated to the late 14th and early fifteenth centuries (Niegoda 1999). Jugs found in the same cultural province (Bohemia) are also typologically similar, in contexts that are of the same date, while others are dated considerably later-the sixteenth and seventeenth centuries (Blažková-Dubská 2009). The Kolno finds however come from a well-defined context predating the destruction of the castle in 1443. Redpainted oxidation-fired wares found in Silesia, areas of possible crop cultivation. The exact position was measured with the coordinate system currently used: epsg projection 2177-etrs89/Poland cs2000 zone 6. Scale is given in meters. Laser surface scan map (LIDAR) was designed by M. Legut-Pintal, and coordinate grid by L. Marek

represented by one of the jugs, are also characteristic of the mentioned period (Niegoda 1999). The exact position of the jugs was measured according to the coordinate system: epsg projection 2177-etrs89/ Poland cs2000 zone 6. The measurement was performed using a GPS RTK device (Hi-Target V30 GNSS) equipped with a Q-Mini controller and HiTarget Hi-RTK Road program. Additionally, a Leica Total Station device (407 Modell) was used to pinpoint the finds on the map (Fig. 2). Thus, the following locations of the finds were recorded:

- Jug A, a red-painted oxidation-fired ceramic vessel -ware with a capacity of $2610 \mathrm{~cm}^{3}$ (total station code: WBZAB.93); coordinates: y $6,476,509.818, \times 5,634,200.494$, h 137.484966 (m a.s.1.). 

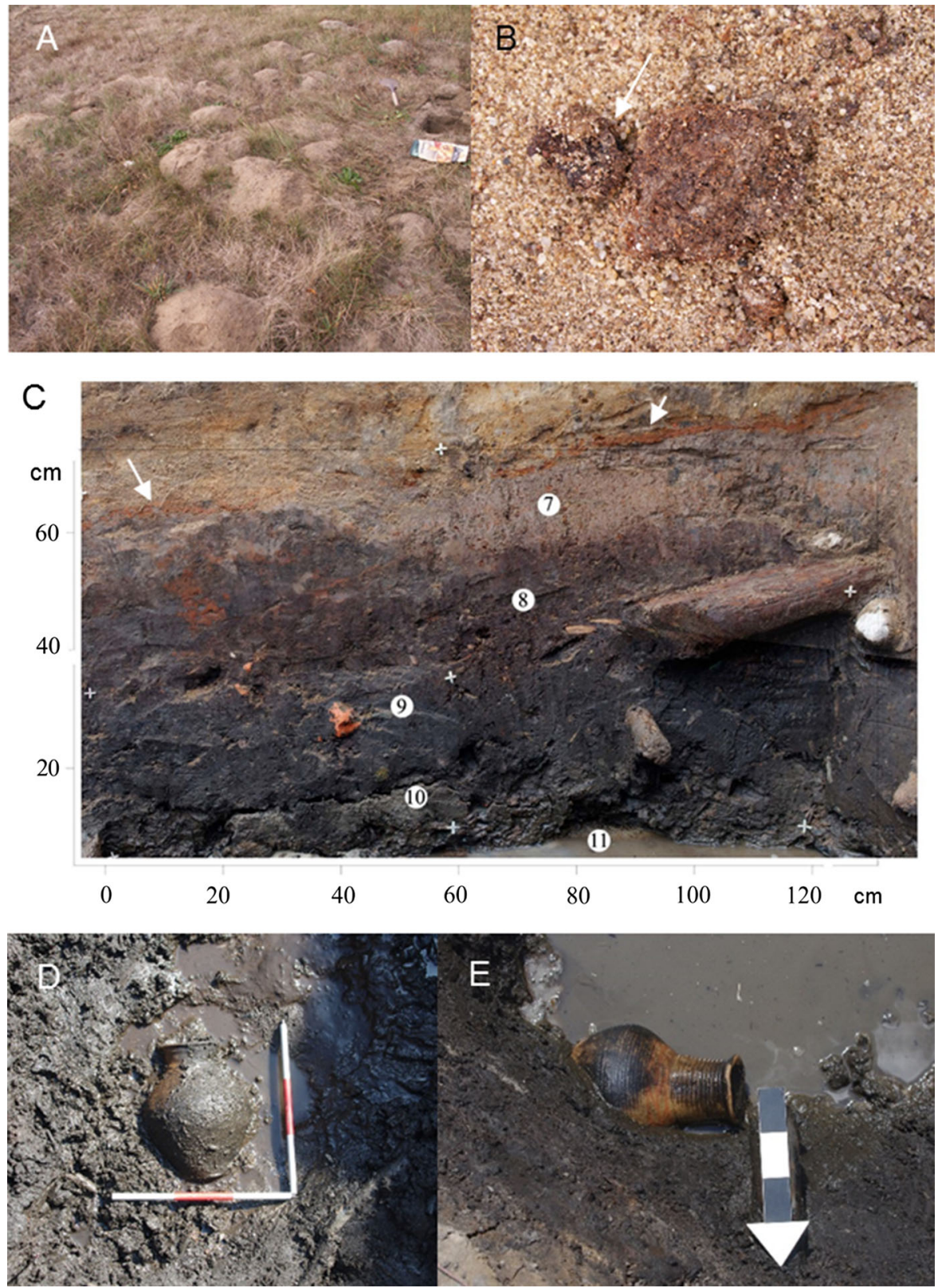

Fig. 3 Soils in the vicinity of the Kolno Castle and artifacts recovered during the archaeological excavation. a-loose alluvial sand elevated by moles on the surface of xerophilous grass; $\mathbf{b}$ - a conglomerate of ferruginous sand with concretions of $\mathrm{FeO}$ (arrow); c-Stare Kolnie 4, trench no. B/2012, eastern quarter. The figure presents an orthophoto image of the southeastern section. Undistorted strata sequence: $7-$ compact, grey river-silt containing very few artifacts; 8 - upper part of the moat fill: the organic matter of plant and animal origin containing archaeological artifacts (context of the jug-finds); 9-lower part of the moat fill: the organic matter mixed with sand; 10 - bottom of the moat fill: river sand mixed with organic matter containing few artifacts; 11 -alluvial, light grey river sand (white arrows show a compact ferruginous layer); $\mathbf{d}-$ jug A in situ; e-jug B in situ. a, b by R. Kosina; c, d, e by L. Marek

- Jug B, an unpainted oxidation-fired vessel with a capacity of $3600 \mathrm{~cm}^{3}$ (total station code:

WBZAB.61); coordinates: y $6,476,509.323, \times$ 5,634,200.356, h 137.362127 (m a.s.1.). 
Archaeobotany

The plant material analysed in the study was collected during an archaeological excavation undertaken in the former moat surrounding the castle (Fig. 2), as well as from two jugs, A and B, found lying horizontally in the moat sediments (Fig. 3d, e). In addition, a sample from the moat sediment $(\mathrm{M})$, having a volume of approximately $2300 \mathrm{~cm}^{3}$, was obtained from the layer with jugs for performing a comparative analysis with their archaeobotanic content. Furthermore, stones and nuts of the cultivated and gathered plants were acquired from several layers of the moat deposit (ML). Organic remains collected from the two jugs contained numerous small diaspores of wild, weedy and cultivated plants, but only a few fragments of stones and nuts. Numerous wild taxa were not included in this study. Layers of the moat deposit are marked by successive letters, from $\mathrm{A}$ (at a depth of $160 \mathrm{~cm}$ ) to $\mathrm{O}$ (at a depth of $200 \mathrm{~cm}$ ). A large collection of fossil and modern plant diaspores maintained by R. Kosina as well as numerous published keys were used to determine the material tested. The botanical nomenclature was applied according to:https://npgsweb.ars-grin.gov/gringlobal/ taxon/taxonomysearch.aspx. http://www.theplantlist. org/.

Stones of domesticated plums, namely Prunus spinosa and Prunus avium (L.) L./Prunus cerasus L. as well as nuts of Corylus avellana were described by the following characters (codes used in correlation matrices are given in brackets) (see also Fig. 4):

- Length of a stone or nut (L)

- Width of a stone or nut (W)

- Height of ventral raphae for a stone (HVR)

- Width of ventral raphae for a stone (WVR)

- Height of gibbosus for a nut (HG)

- W/L and HG/L ratios

Gibbosus is a central structure of cicatrix carpica (nut scar) surrounded by a sclerenchymatous rim showing a varied morphology (Kosina 1991). It can be convex, flat, or in rare cases slightly concave. Gibbosus directly contacts the abscission zone, developed between the pedicel and the nut (Roongsattham et al. 2016), through which a single bundle penetrates in the center of the structure toward the ovules (Hagerup 1942) and numerous other bundles branch into the pericarp (Sheng et al. 2019). The measured characters were selected from a larger set of data presented by

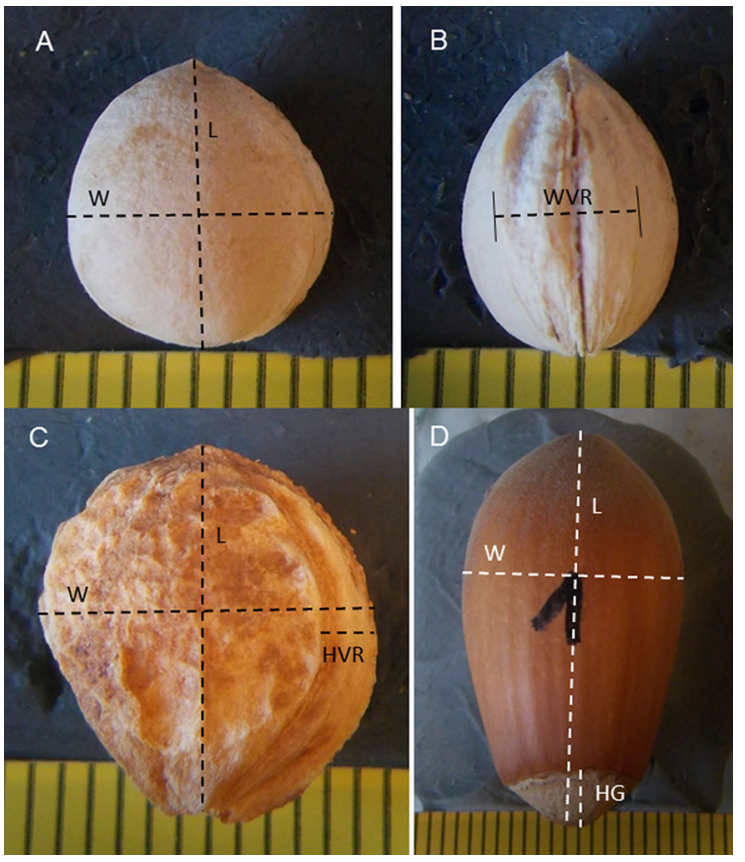

Fig. 4 Measurements of characters (broken lines) of the stones of Prunus avium/P. cerasus (a, b) and P. domestica subsp. syriaca (c) and filbert nuts (d) to describe their variability (stones and nuts were marked with numbers or dots for identification during morphometric analysis). Scale in $\mathrm{mm}$

Staszak (2004) for plum stones and by Kosina (1991) in the case of filbert nuts. Each stone or nut was treated as an operational taxonomic unit (OTU) and marked in diagrams and photos by a letter (a moat layer) and a number (an individual within the layer).

The fossil material was compared with contemporary types of stones and nuts collected in sites marked on the map of Poland (Fig. 5). To obtain a representative range of characters, the contemporary OTUs phenotypically distinctly different from each other were selected from large samples, while diaspores with intermediate morphology were not chosen for comparisons. This procedure allowed to decrease the size of analysed samples. These OTUs are marked by letters as follows and numbered for individuals:

Pd - Prunus domestica L. subsp. domestica.

$\mathrm{Pi}$-Prunus domestica subsp. insititia (L.) C. K. Schneid.

Psy - Prunus domestica subsp. syriaca (Borkh.) Janch. ex Mansf.

Ps - Prunus spinosa L.

$\mathrm{Pa}-$ Prunus avium (L.) Lss/P. cerasus $\mathrm{L}$.

$\mathrm{Ca}-$ Corylus avellana $\mathrm{L}$. 


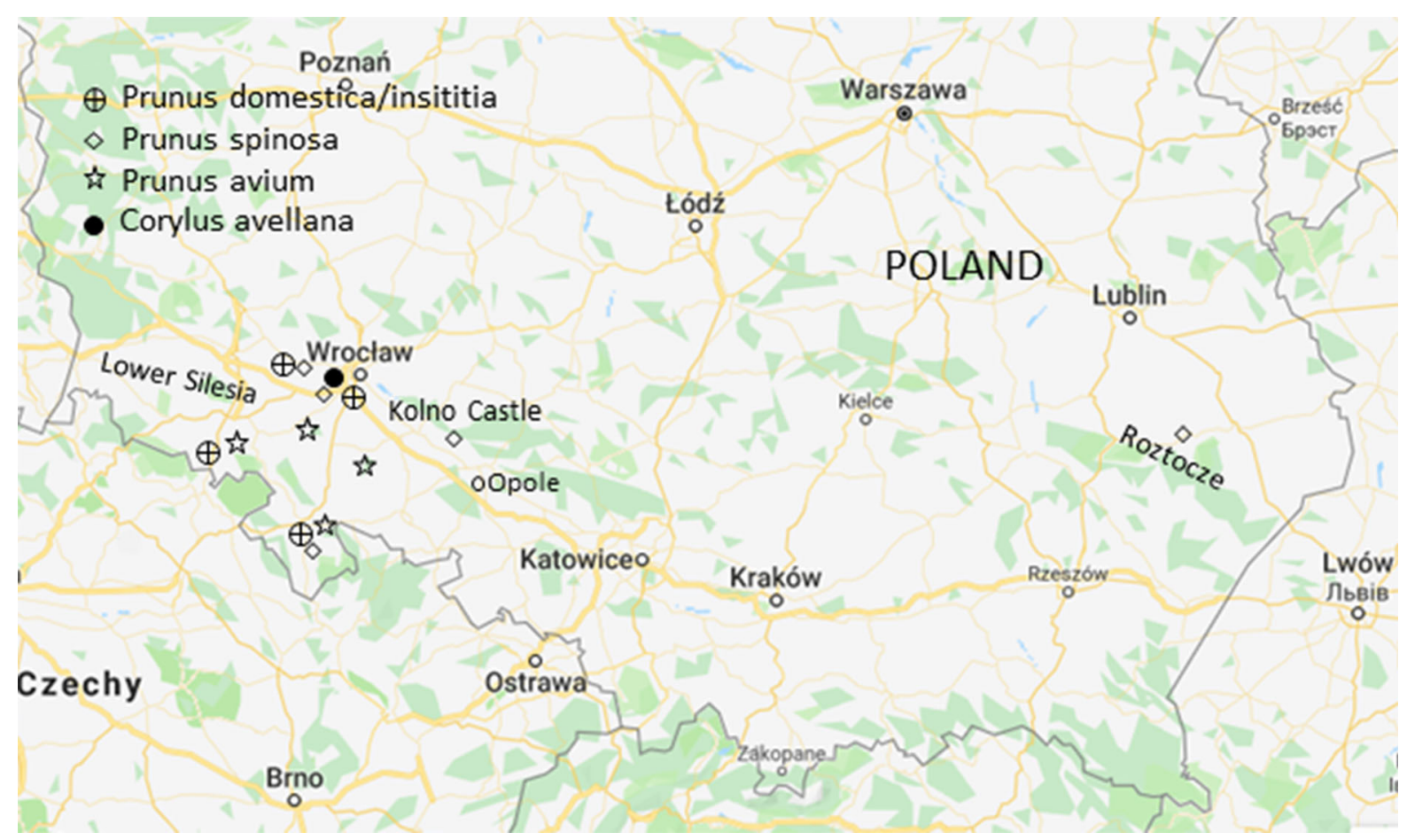

Fig. 5 Map of southern Poland showing the locations from where contemporary plums, cherries and filbert nuts were collected to compare their variations with fossil specimens from Kolno. Based on Google Maps (modified)

A matrix of average taxonomic distances between OTUs within a given set was generated. This matrix was transformed into a configuration matrix using the Kruskal's method of non-metric multidimensional scaling (nmMDS), and the configuration matrix was later applied to set the OTUs in a minimum spanning tree (MST) in a three-dimensional $(x, y, z)$ ordination space (see Figs. 6, 8, 11, 13, and 15). Numerical analyses were performed using NTSYS software (Rohlf 1994).

\section{Results and discussion}

Crop plants and weeds

It is highly probable that the backwater of the Budkowiczanka River was used to build the moat with water flowing around the castle (see Figs. 1, 2). Sediments in the moat are differentiated by the movement of water in the moat that depends on the seasonal fluctuations of the water level. The spatial layout of the Budkowiczanka River and its branch forming the moat from the east and departing from the river at an angle of approximately $90^{\circ}$ (Fig. 1) indicates that the water movement in the moat was rather weak, but could have been stronger during the flood. The deposit is supplemented by rubbish, thrown into the moat. This also applies to the two jugs, the contents of which were studied in the present work. The jugs contained plant remains which had been deposited in them by a user or by water inflow. The latter was possible because the jugs were found deposited horizontally.

The analysed plant material was not a large collection of diaspores or their fragments of a single species; however, species diversity determines its high value for the archaeobotanical knowledge of the site. Plant macroremains represent a wide range of habitats and uses. Diaspores of crops and weeds were identified mainly in the jug content and the moat sample (M). The capacity of the jugs, which was approximately 3-4 L, seemed to be optimal for carrying seeds or other small diaspores.

Species of plants cultivated around the castle on fields or in gardens are presented in Table 1, and species of weeds in Table 2 . 
Some crops, such as rye and millet (Table 1), could be grown near the castle on larger plots, in higher places, free from flooding or shortly flooded (see Fig. 2). This applies particularly to millet, which in Polish conditions, in lowered and wet places, shows poor yield potential or even dies (Lewicki 1928). The detected millet remains belong to four varieties with yellow, light brown, red and gray-green glumellae. A mixture of these varieties was probably cultivated in which the yellow variety dominated. In Polish conditions, the yellow variety gives high and stable yields (Lewicki 1928). Many mediaeval archaeobotanical materials recovered from Lower Silesia (thirteenth century) showed that millet cultivation reaches $30 \%$ (Kosina 1992). The most commonly found was the type of millet with yellow glumellae, while other types, including semi-wild, were found rarely (Kosina and Tomaszewska 2013).

Among all the plant remains, only one charred rye caryopsis was found in jugs (Table 1). In the moat sample (M), a fragment of charred rye caryopsis was also detected. Due to rye hardiness and stable yields, even on light soils, it could be cultivated on alluvial sands in the vicinity of the castle (Fig. 3a, b). The layer of the conglomerated ferruginous sand, which is not good for plant vegetation but appearing at a depth of $40-50 \mathrm{~cm}$ (in a moat at a depth of approximately $140 \mathrm{~cm}$, Fig. 3c), did not significantly affect the development of roots in cereals. In the 13th century, both cereals, (rye and millet), were widely cultivated near Wroclaw (Kosina 1995), a city located on the Odra River, towards the northwest from the Kolno Castle (Fig. 5). Fossil material collected from the Kolno Castle can also be compared with materials from Opole, a settlement also located on the Odra River, to the southeast of Kolno (Fig. 5). From the 10th to the 12th century millet was widely cultivated on the settlement, and in the 12th century, rye cultivation was also increased (Klichowska 1956). The importance of millet and rye in the Middle Ages has also been marked in many other places in Lower Silesia (Kosina 1991). The cultivation of various cereals, including rye and millet, was frequent in northern Europe (Greig 1983). Rye has been established as a major corn in the high Middle Ages, especially in Germany and Central Europe (Behre 1992).

Other Kolno crops (Table 1), including hemp (Cannabis sativa L.), flax (Linum usitatissimum L.), poppy (Papaver somniferum L.), and cabbage (Brassica oleracea $\mathrm{L}$. or also other species of this genus) were probably grown on smaller, garden plots with more fertile soil. Large amounts of macroremains of hemp and flax were found in the 12th-century castle in Opole (Klichowska 1956), while in the 11th century in Wroclaw the amount of flax was estimated at $75 \%$
Table 1 Crop plants cultivated on fields and gardens that were collected from the two jugs (A and B), the moat sample and the moat deposit obtained during archaeological excavation

d, s, f-diaspores, stones, fragments, respectively; the depth of deposition in the moat $(\mathrm{cm})$ is given in brackets

\begin{tabular}{|c|c|c|c|c|}
\hline Species of crop plants & $\begin{array}{l}\text { Jug A(2) } \\
(185)\end{array}$ & $\begin{array}{l}\text { Jug B(1) } \\
(180-185)\end{array}$ & $\begin{array}{l}\text { Moat sample } \\
\text { (M) }\end{array}$ & Moat deposit(ML) \\
\hline \multicolumn{5}{|l|}{ Crops } \\
\hline Secale cereale L. & $1 d$ & & 1f & \\
\hline Panicum miliaceum $\mathrm{L}$. & $3 f$ & & $50 f$ & \\
\hline Cannabis sativa $\mathrm{L}$. & $2 \mathrm{f}$ & $1 d$ & $16 f$ & \\
\hline Linum usitatissimum $\mathrm{L}$. & & $3 d$ & $1 d+3 f$ & \\
\hline Papaver somniferum L. & $5 d$ & & & \\
\hline Brassica oleracea L. & $4 d$ & $1 d$ & $2 d+38 f$ & \\
\hline $\begin{array}{l}\text { Brassica nigra (L.) W.D.J. Koch } \\
\text { Fruit trees }\end{array}$ & $2 \mathrm{~d}+2 \mathrm{f}$ & & 9f & \\
\hline $\begin{array}{l}\text { Prunus domestica L. } \\
\text { subsp. domestica }\end{array}$ & & 1f & & $\begin{array}{l}3 \mathrm{~s}(165) 2 \mathrm{~s}(170) \\
1 \mathrm{~s}(185) 1 \mathrm{~s}(200)\end{array}$ \\
\hline $\begin{array}{l}\text { Prunus domestica L. } \\
\text { subsp. insititia } \text { C.K. Schneid }\end{array}$ & & 1f & & $2 \mathrm{~s}(170)$ \\
\hline Prunus persica (L.) Batsch & & & 1f & $1 \mathrm{~s}(165) 1 \mathrm{~s}(190)$ \\
\hline Juglans regia $\mathrm{L}$. & & & & $2 \mathrm{f}(190)$ \\
\hline
\end{tabular}


Table 2 Weeds collected from the two jugs and a moat sample d, f-diaspores, fragments, respectively

\begin{tabular}{|c|c|c|c|}
\hline Species of weeds & $\begin{array}{l}\text { Jug A } \\
(185)\end{array}$ & $\begin{array}{l}\text { Jug B } \\
(180-185)\end{array}$ & $\begin{array}{l}\text { Moat sample } \\
\text { (M) }\end{array}$ \\
\hline \multicolumn{4}{|l|}{ Weeds } \\
\hline \multicolumn{4}{|l|}{ Secalinetea and accompanied } \\
\hline Agrostemma githago $\mathrm{L}$. & $6 d+4 f$ & $7 \mathrm{~d}$ & $16 f$ \\
\hline Centaurea cyanus $\mathrm{L}$. & & & $1 \mathrm{~d}$ \\
\hline Anthemis arvensis $\mathrm{L}$. & & & $5 \mathrm{~d}$ \\
\hline Galeopsis tetrahit $\mathrm{L}$. & $1 \mathrm{~d}$ & & \\
\hline Galeopsis ladanum L. & $2 \mathrm{~d}$ & & $3 \mathrm{~d}$ \\
\hline Rumex acetosella $\mathrm{L}$. & $10 \mathrm{~d}$ & $5 \mathrm{~d}$ & $74 d+17 f$ \\
\hline Fallopia convolvulus (L.) Á. Löve & $4 d+3 f$ & $3 \mathrm{~d}$ & $7 d+5 f$ \\
\hline Thlaspi arvense $\mathrm{L}$. & & $1 d$ & \\
\hline Viola arvensis Murr & & & $6 d+2 f$ \\
\hline Neslia paniculata (L.) Desv & & & $2 f$ \\
\hline Spergula arvensis $\mathrm{L}$. & & $2 \mathrm{~d}$ & \\
\hline \multicolumn{4}{|l|}{ Chenopodietea and accompanied } \\
\hline Setaria glauca (L.) P. Beauv & $6 \mathrm{~d}$ & $1 d+2 f$ & $6 d+56 f$ \\
\hline Echinochloa crus-galli (L.) P. Beauv & & $1 d$ & \\
\hline Solanum nigrum $\mathrm{L}$. & $7 \mathrm{~d}$ & $7 \mathrm{~d}$ & $15 d+4 f$ \\
\hline Polygonum persicaria $\mathrm{L}$. & $6 \mathrm{~d}$ & & $8 d+1 f$ \\
\hline Polygonum nodosum Pers & $13 \mathrm{~d}$ & $9 \mathrm{~d}$ & $18 d+7 f$ \\
\hline Rumex crispus $\mathrm{L}$. & & & $3 d$ \\
\hline Silene latifolia Poir & & & $7 d+1 f$ \\
\hline Urtica urens $\mathrm{L}$. & $2 \mathrm{~d}$ & & \\
\hline Stellaria media (L.) Vill & $3 \mathrm{~d}$ & & $15 d+2 f$ \\
\hline Chenopodium album $\mathrm{L}$. & $32 \mathrm{~d}$ & $14 \mathrm{~d}$ & $84 \mathrm{~d}$ \\
\hline Chenopodium polyspermum $\mathrm{L}$. & $3 d$ & $1 d$ & $15 \mathrm{~d}$ \\
\hline Chenopodium sp. & $7 \mathrm{~d}$ & & \\
\hline Atriplex sp. & & $2 \mathrm{~d}$ & \\
\hline
\end{tabular}

(Kosina 1977). Flax also has a long history of cultivation in north-western Europe (Greig 1983). During archaeological excavations, Papaver somniferum is noted in a small amount. In north-western Europe, its findings are scattered (Greig 1983). The review data from Czechoslovakia and Poland show the amount of this plant in admixture (Wasylikowa et al. 1991), but in mediaeval Kiel (Wiethold 1995) and in Brussels (Speleers and van der Valk 2017) it is more frequent, especially in cesspits. This species has been cultivated in south-western Germany since Early Neolithicum up to the modern time (Rösch 1998). The early mediaeval data from Wroclaw present its amount below 2\% (Kosina 1981).

Other, more elevated sites (Fig. 2) have also been used as small gardens for growing fruit trees. The stones of Prunus L. and nuts of Juglans regia L. detected in the moat fossils (Table 1) were probably deposited directly from trees growing on the castle hill, but these macroremains can also be rubbish thrown by humans. Two subspecies of domesticated plums, $P$. domestica subsp. domestica and $P$. domestica subsp. insititia, were cultivated.

Stones of plums, especially Prunus domestica L., are numerous in the mediaeval layers of Opole and Wroclaw, but Prunus persica (L.) Batsch and Juglans regia are not so frequent (Klichowska 1956; Kosina 1995). The frequency of $P$. domestica subsp. domestica is higher than that of subsp. insititia. At the same time, sloe plums were used instead of domesticated plums in Wroclaw in the period between 975 and 1250 $\mathrm{AD}$, probably due to the unfavourable weather conditions during the flowering time and poor fruitifying of the latter (Kosina 1992). In northern Europe, $P$. 
domestica is noted as frequent, but not $P$. persica (Greig 1983). Mediaeval remnants of domesticated plums are numerous in Poland and Czechoslovakia, and in the latter, subsp. insititia dominates over subsp. domestica (Wasylikowa et al., 1991). Large samples of the stones Prunus insititia L. recovered from mediaeval and post-mediaeval sites in Lübeck, AltSchleswig and Haithabu prove that the cultivation of plums in northern Germany was also common (Kroll 1980).

All crop plants determined in the Kolno fossils could also be delivered to the castle from the nearby village Alt Köln (Fig. 1). This is probable but not proven by the available material.

The types of weed diaspores belonging to two phytosociological classes, Secalinetea and Chenopodietea (Table 2), indicated two types of crop cultivation: field and garden. Agrostemma githago L., Fallopia convolvulus (L.) Á. Löve and Rumex acetosella $\mathrm{L}$. were found to predominate quantitatively among the cereal weeds. $R$. acetosella and Spergula arvensis L. were markers of the poor sandy soils. Some other weeds growing on cereal fields, including Centaurea cyanus L. and Anthemis arvensis L., were detected in the moat sample (M). Among the weeds of the garden crops and the late-sown millet, the diaspores of Polygonum nodosum Pers. and Chenopodium album $\mathrm{L}$. were dominating. The numbers of diaspores of the different species found in the moat sample (M), often as fragments, were frequently higher than in jugs. Plants detected in the jugs and moat of the same layer showed a similar composition of taxa. A significant difference found in the preservation of the Agrostemma githago diaspores-whole seeds in jugs versus fragments in the moat-may indicate the intentional content of rye and cockle in the jugs. The jugs protected cockle seeds against fragmentation. In addition, many diaspores of the local wild plants were detected in the jugs. They were not associated with any crops, and were deposited in the jugs by water movement in the moat.

The most numerous weeds recovered from Kolno have also been documented from many sites in Poland from the early Middle Ages and are attributed to plant syntaxa, Centauretalia cyani and PolygonoChenopodietalia (Lityńska-Zając 2005). Agrostemma githago, Fallopia convolvulus and Chenopodium album were also found in many mediaeval localities in Central Europe, and their scattering seems to be correlated (Willerding 1981). The older archaeobotany data from Opole (Klichowska 1956) do not permit the quantitative comparison of weeds from this locality with the Kolno weeds. The data from crop granaries in the early mediaeval Wroclaw show that among cereal weeds, Agrostemma githago always dominates, while Fallopia convolvulus and Rumex acetosella constitute $5 \%$ or less (Kosina 1977, 1978, 1981). A set of weeds detected from large cereal samples from the 11th century $\mathrm{AD}$ in Wroclaw is characteristic of Vicietum tetraspermae associated with rye cultivation (Kosina 1977). It can develop on various soils, for example deep loess or sand (Wasylikowa 1981). Such a weed association is not documented in the Kolno locality, probably due to the small number of specific diaspores recovered; however, it could grow on the ferruginous sands of the site.

\section{Gathered plants}

The identified macrofossils were remains of the gathered plants consumed by humans (most species), as well as by animals, e.g. oak acorns (Table 3).

Among the gathered plants, the stones of putative hybrids between domestic plums and sloe are particularly interesting (Table 3). These stones show the dominance of the sloe characters, probably due to a maternal parent influence. Similar types of hybrids are described by Pollmann et al. (2005). Among the gathered plants, the most numerous are diaspores and their fragments of Prunus avium/Prunus cerasus and Corylus avellana. Wild cherry trees and filbert bushes probably also grew on the castle hill and their diaspores might have sunk to the bottom of the moat directly from these specimens or as waste after human consumption. Two stones of Cornus sanguinea L. could be deposited from a shrub growing on the hill, or it could be brought by water. This shrub grows commonly in riverside forests; however, it can fruitify mainly in the sunny sites (R. Kosina, unpublished). Its black, tart fruits were rather processed (juice) than directly consumed. 
Table 3 Gathered plants in the vicinity of the castle

\begin{tabular}{|c|c|c|c|c|c|c|c|c|c|c|}
\hline \multirow[t]{2}{*}{$\begin{array}{l}\text { Species of } \\
\text { gathered plants }\end{array}$} & \multirow[t]{2}{*}{$\begin{array}{l}\text { Jug A } \\
(185)\end{array}$} & \multirow[t]{2}{*}{$\begin{array}{l}\text { Jug B } \\
(180-185)\end{array}$} & \multirow{2}{*}{$\begin{array}{l}\text { Moat } \\
\text { sample } \\
(\mathrm{M})\end{array}$} & \multicolumn{7}{|c|}{$\begin{array}{l}\text { Moat deposit (ML) } \\
\text { Depth from the ground surface }(\mathrm{cm})\end{array}$} \\
\hline & & & & $140-150$ & $150-160$ & $160-170$ & $170-180$ & $180-190$ & $190-200$ & 205 \\
\hline Rubus idaeus L. & $1 d$ & & $4 d$ & & & & & & & \\
\hline Rubus caesius L. & & $2 \mathrm{~d}$ & $5 \mathrm{~d}$ & & & & & & & \\
\hline $\begin{array}{l}\text { Humulus lupulus } \\
\text { L. }\end{array}$ & $6 d+5 f$ & $1 d$ & $\mathrm{nf}$ & & & & & & & \\
\hline Fragaria vesca L. & $3 d$ & $2 d$ & $10 \mathrm{~d}$ & & & & & & & \\
\hline Prunus spinosa L. & & $1 \mathrm{~s}$ & & & & $5 \mathrm{~s}$ & $1 \mathrm{~s}$ & $1 \mathrm{~s}$ & & \\
\hline $\begin{array}{l}\text { P. spinosa L./ } \\
\text { Prunus } \\
\text { domestica } \\
\text { subsp. insititia } \\
\text { (L.) C. } \\
\text { K. Schneid }\end{array}$ & & $1 \mathrm{~s}$ & & & & $3 \mathrm{~s}(170)$ & & $1 \mathrm{~s}(190)$ & & \\
\hline $\begin{array}{l}\text { P. spinosa L./ } \\
\text { Prunus } \\
\text { domestica } \\
\text { subsp. syriaca } \\
\text { (Borkh.) Janch. } \\
\text { ex Mansf }\end{array}$ & $1 \mathrm{~s}$ & & & & & & & $1 \mathrm{~s}(190)$ & & \\
\hline $\begin{array}{l}\text { Prunus avium } \\
\text { (L.)L./Prunus } \\
\text { cerasus L. }\end{array}$ & & & $1 \mathrm{~s}$ & & & $13 \mathrm{~s}$ & & $8 \mathrm{~s}$ & $6 \mathrm{~s}$ & \\
\hline $\begin{array}{l}\text { Cornus sanguinea } \\
\text { L. }\end{array}$ & & & $1 \mathrm{~s}$ & & & $1 \mathrm{~s}$ & & & & \\
\hline $\begin{array}{l}\text { Corylus avellana } \\
\text { L. }\end{array}$ & & & $\mathrm{nf}$ & $2 f$ & $15 f$ & $4 d+65 f$ & $3 d+39 f$ & $1 d+76 f$ & $1 d+15 f$ & $2 d+6 f$ \\
\hline Quercus robur L. & & & $7 f$ & & & $1 \mathrm{c}$ & & $1 \mathrm{c}$ & & \\
\hline $\begin{array}{l}\text { Lathyrus } \\
\text { tuberosus L. }\end{array}$ & & & & & & $1 \mathrm{t}(165)$ & & 1t (190) & & \\
\hline
\end{tabular}

$\mathrm{c}, \mathrm{d}, \mathrm{f}, \mathrm{s}, \mathrm{t}, \mathrm{n}$-cupula, diaspores, fragments, stones, tubers, numerous, respectively

The depth of deposition in the moat $(\mathrm{cm})$ is given in brackets

Variability of stones and nuts

\section{Correlations of stone characters of Prunus}

Two dimensions of the stone, width and length, are most correlated $(r=0.93 * * *)$ in Prunus insititia/P. domestica (Table 4). The elongation growth of the stone is a significant component of the fruit development in this species and the variation of growth increases the level of correlation of the characters. In other plums, these correlation coefficients are also significant but lower, e.g. almost twice lower in $P$. spinosa. The elongation growth is not so variable in the other species, sloe and wild cherry, and hence, the correlations are smaller in them. In domesticated plums, the growth of a ventral raphae (HVR) is highly coordinated with the development of the stone as a whole, but this is not true for $P$. spinosa showing insignificant coefficients of correlation for HVR. Similarly, insignificant coefficients of correlation are noted for the width of ventral raphae (WVR) in cherries. In a mixed sample of OTUs composed of domesticated plums and sloe, the coefficients of correlation are increased compared to a pure sample of sloe. The development of HVR or WVR is not related to the shape of the stone. In general, the 


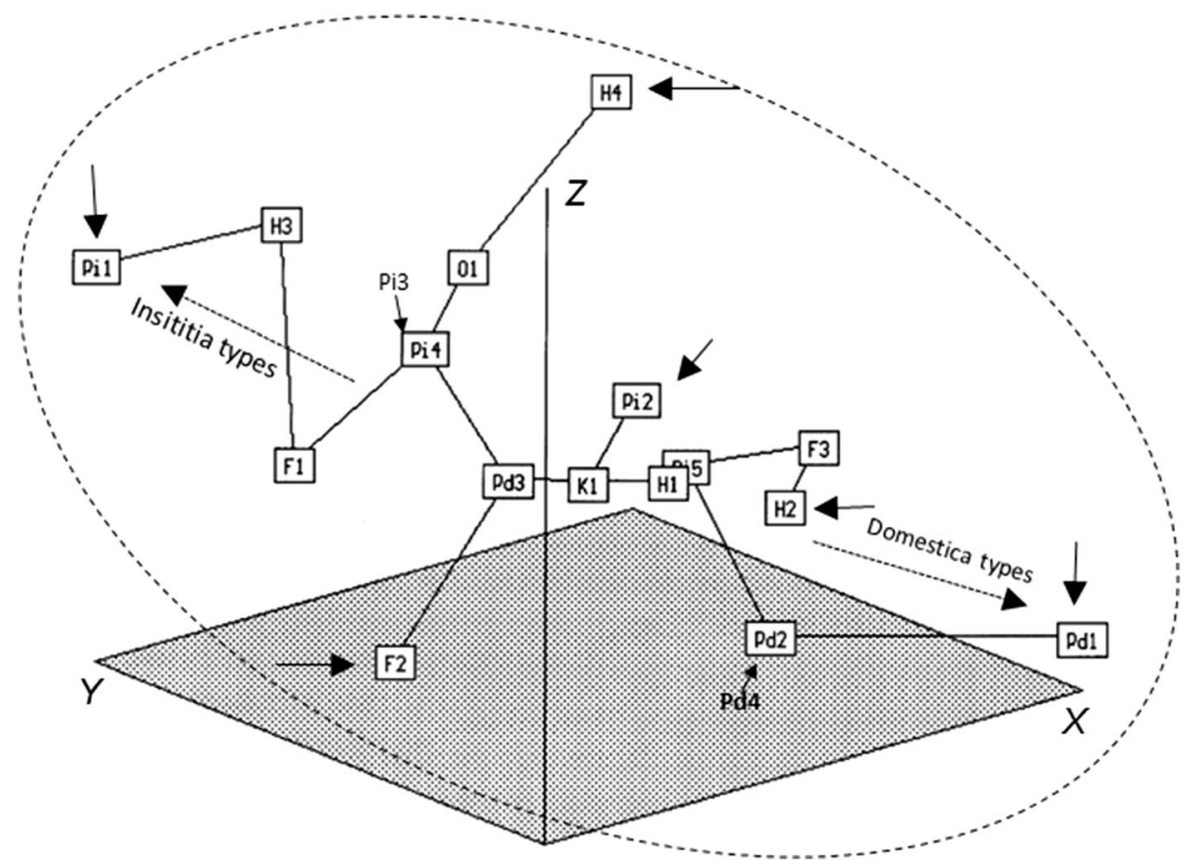

Fig. 6 Minimum spanning tree (MST) of the contemporary and fossil stones (OTUs) of domesticated plums, Prunus domestica subsp. domestica $(\mathrm{Pd})$ and subsp. insititia $(\mathrm{Pi})$ in an ordination space ( $x, y$, and $z$ axes) and created by application of Kruskal's non-metric multidimensional scaling method (Rohlf 1994). The same numerical method has been applied for the other MST

matrices of correlation coefficients among various Prunus show some similarity, indicating that the development of Prunus stones is conservative. The similarity of their embryological development has been evidenced by Sterling (1964). The external sculpture of the stone is formed by many lateral smaller vascular bundles, while a dorsal raphae develops adjacent to a large bundle. A large vascular plexus is located within the ventral raphae. For a large set of the contemporary sloe stones, Staszak (2004) proved that three basic dimensions of the stone, their ratios and dimensions of both raphae plus their ratios, create three distinct clusters when a matrix of the Pearson's correlation coefficients and the UPGMA method of clustering are applied. A similar result has been obtained for the same group of characters using the method of non-metric multidimensional scaling ordination.

Most of the interrelations between the 11 stone characters of Prunus spinosa are described by statistically significant correlation coefficients and linear regressions; however, the dependence between the diagrams. OTUs were described by four traits of the stone. For abbreviations, see 'materials and methods'. Extreme OTUs are marked by short arrows. Ellipse encircles a cloud of OTUs (the same applies to Figs. 8, 11, 13, 15). Pi3 and Pd4 are hidden behind other OTUs

width of the stone and the shape of the ventral raphae is well illustrated by a curvilinear regression (Kosina 2005). This confirms that the development of raphae shows some specificity.

\section{Ordination of Prunus OTUs}

\section{Prunus domestica sensu lato}

Morphotypes Pi1 and Pd1 are extreme OTUs in an ordination space (Fig. 6). They determine the directions of variability for two subspecies domestica and insititia. Other OTUs of these two subspecies, both contemporary and fossil, are intermediate between them. There is no clear discrimination between the two subspecies. The cloud of OTUs (plum stones) in the ordination space creates a characteristic ellipsoid stretched between the values of $x$-max, $y$-min, $z$-min for Pd1 and $x$-min, $y$-max, $z$-max for Pi1. This indicates the negative correlations of the values of OTUs on ordination axes $x / y$ and $x / z$ and positive correlation for $y / z$, and different regression lines 
Table 4 Pearson's coefficients of correlation of stone characters of Prunus

\begin{tabular}{|c|c|c|c|}
\hline \multicolumn{4}{|c|}{ Prunus insititia/P. domestica $(n=18)$} \\
\hline Characters & $\mathrm{L}$ & $\mathrm{W}$ & HVR \\
\hline W & $0.93 * * *$ & & \\
\hline HVR & $0.61^{* *}$ & $0.65^{* *}$ & \\
\hline $\mathrm{W} / \mathrm{L}$ & $-0.85 * * *$ & $-0.61 * *$ & $-0.33 \mathrm{~ns}$ \\
\hline \multicolumn{4}{|c|}{ Prunus spinosa $(n=28)$} \\
\hline $\mathrm{W}$ & $0.46^{* *}$ & & \\
\hline HVR & $0.28 \mathrm{~ns}$ & $0.31 \mathrm{~ns}$ & \\
\hline $\mathrm{W} / \mathrm{L}$ & $-0.42 *$ & $0.61 * * *$ & $0.04 \mathrm{~ns}$ \\
\hline
\end{tabular}

Prunus spinosa and domesticated plums

$(n=32)$

\begin{tabular}{llll}
$\mathrm{W}$ & $0.65 * * *$ & & \\
$\mathrm{HVR}$ & $0.52 * *$ & $0.57 * * *$ & \\
$\mathrm{~W} / \mathrm{L}$ & $-0.55 * * *$ & $0.25 \mathrm{~ns}$ & $-0.09 \mathrm{~ns}$ \\
Prunus avium/P. & cerasus $(n=29)$ & & \\
$\mathrm{W}$ & $0.57 * * *$ & & \\
$\mathrm{WVR}$ & $0.18 \mathrm{~ns}$ & $0.31 \mathrm{~ns}$ & \\
$\mathrm{~W} / \mathrm{L}$ & $-0.40 *$ & $0.53 * *$ & $0.15 \mathrm{~ns}$ \\
\hline
\end{tabular}

$*$, **, ***-significance level at $\alpha=0.05,0.01,0.001$, respectively

ns-non-significant, The sample size is shown in brackets

correspondingly (deduced from the scattering of OTUs during rotation of the ellipsoid).

Morphotypes with extreme positions in the ordination space are marked in the diagram with arrows (Fig. 6), and shown in Fig. 7. The extreme morphotypes, Pd1 vs Pi1, are discriminated by the elongation growth of the fruit, and hence their $\mathrm{W} / \mathrm{L}$ ratio reaches the minimum and maximum values in the OTUs set (51 and 74, respectively). The comparison of the morphology of stones, e.g. Pd1 vs Pi1, proves that this elongation growth is localised at the bottom of the stone. Both types of stones were collected from the old trees cultivated in Lower Silesia before 1945 (Fig. 5). Extreme values (min-max) of HVR (height of ventral raphae) were noted in the fossil stones (H4 and F2, respectively) (compare in Fig. 7).

Three basic dimensions of the stone and their ratios measured in a large set of macrofossils from Haithabu and Old Schleswig appeared to be useful to discriminate four types within Prunus domestica (Behre 1978). A fossil type D mentioned in Behre's data is
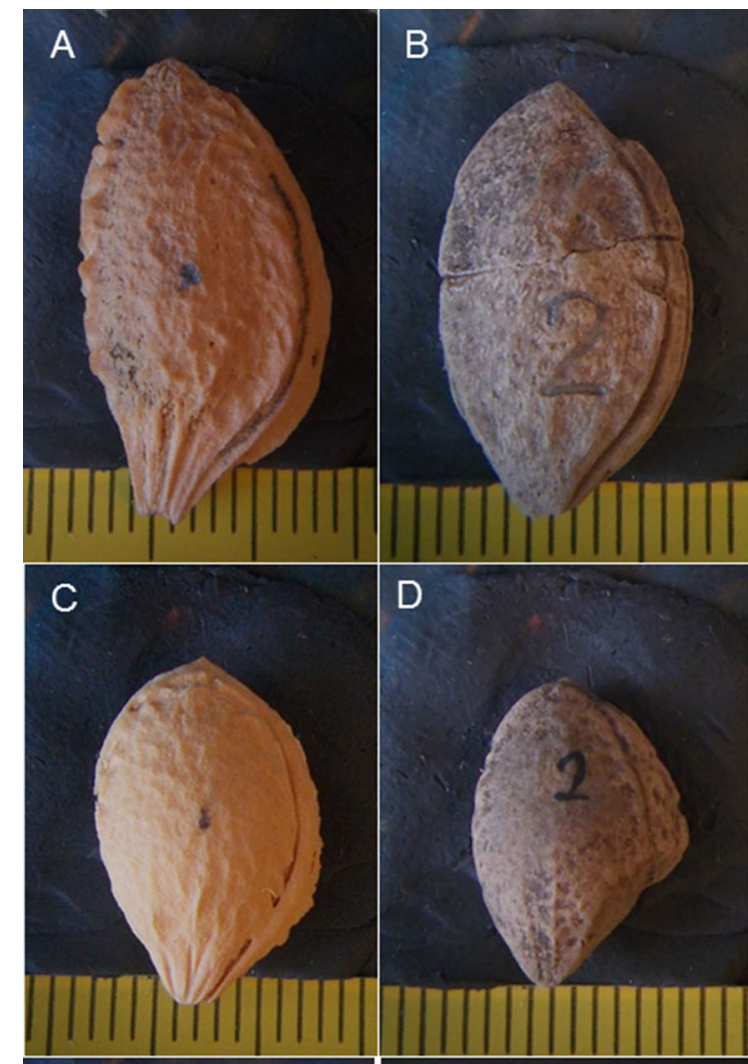

D

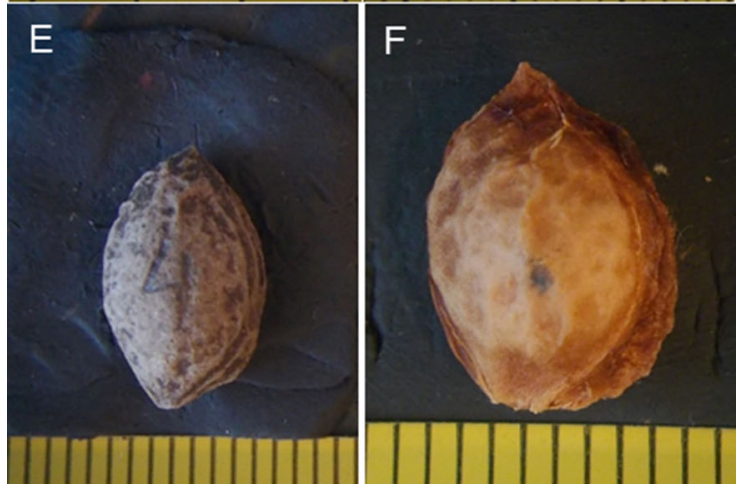

Fig. 7 Morphotypes of fossil and contemporary stones of Prunus domestica sensu lato occupying extreme positions in the minimum spanning tree (see Fig. 6). a-Pd1; b- $-\mathrm{H} 2 ; \mathbf{c}-\mathrm{Pi} 2$; d-F2; e-H4; f-Pi1. Scale in $\mathrm{mm}$

present today in an old abandoned garden in the Sudeten Mts. Foreland, Lower Silesia (see Fig. 7F). Different numbers of types have been distinguished for the stones collected in the mediaeval excavations: six for $P$. insititia from Lübeck (Kroll 1980), four for $P$. insititia from Seehausen (Lange 1988), four for $P$. domestica from Douai (van Zeist et al. 1994) and 13 for $P$. domestica from Groningen (van Zeist and 


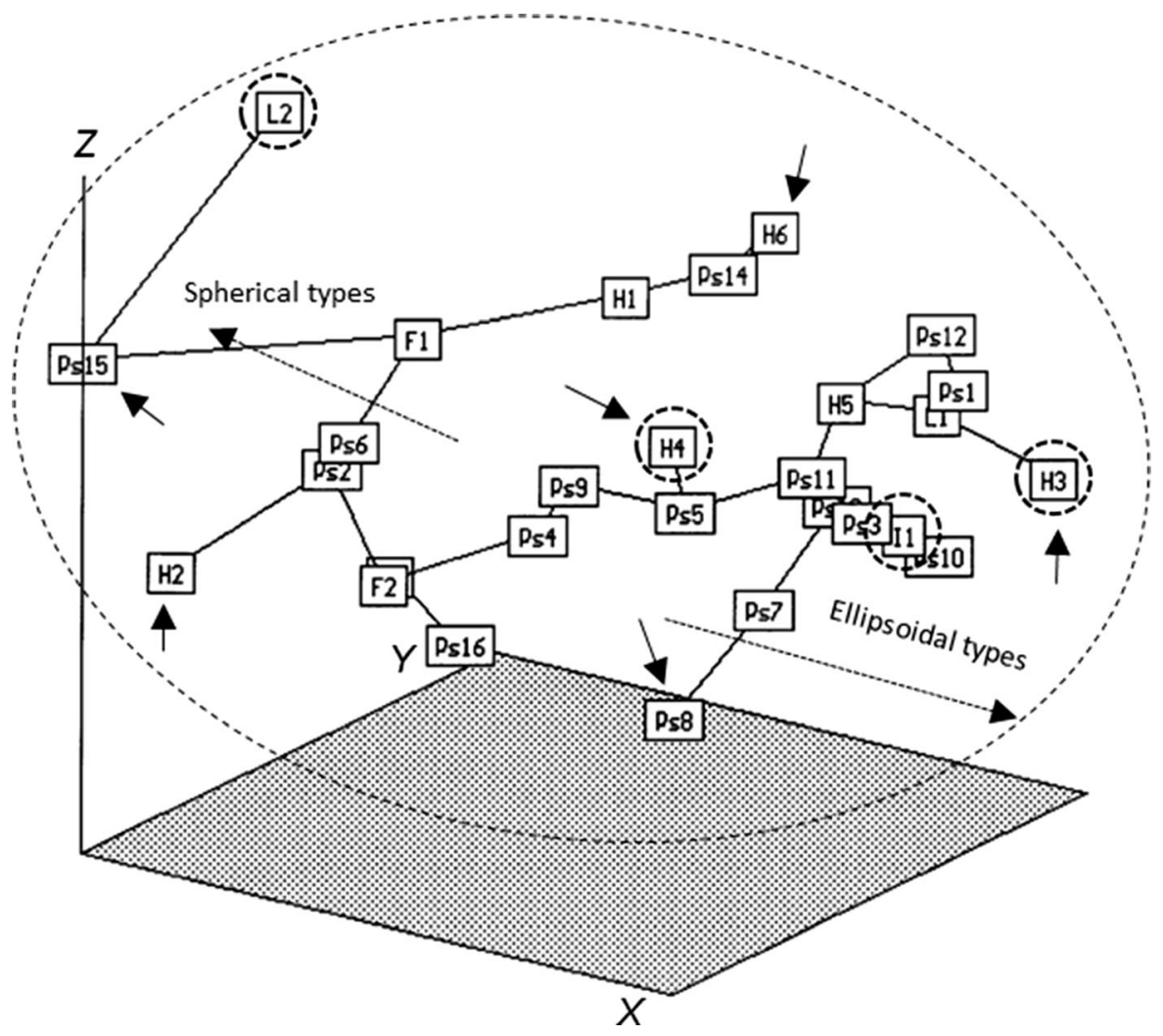

Fig. 8 Minimum spanning tree of the contemporary and fossil stones (OTUs) of Prunus spinosa in an ordination space ( $x, y$, $z$ axes). OTUs were described by four traits of the stone.

Woldring 1997/1998). According to the authors, $P$. domestica is considered as one species or a species with two subspecies, domestica and insititia. They measured three basic characters of a stone: lengthLänge (L), width - Breite (W or B) and thickness Dicke (T or D) (Behre 1978). Another designation of stone characters is presented by Horvath et al. (2011) and Nielsen and Olrik (2001) where width (W) equals Dicke (D) and thickness (T) equals Breite (B). The data of Horvath et al. (2011) show the lack of variation of the stone thickness within the group of 80 varieties of. P. domestica from France and indicate the uselessness of this feature.

The above aspect of character designation needs some explanation. The plum fruit is a transformed carpel (leaf) (Sterling 1964), and so the development of the stone (a part of the carpel) and the embryo in it with two cotyledons can be approximated to the development of the leaf. Periclinal cytokineses increase the number of cell layers indicating the
Extreme OTUs are marked by short arrows. Putative hybrids between $P$. spinosa and domesticated plums are encircled by a broken line. Abbreviations see in 'materials and methods'

increase of the leaf thickness, and anticlinal ones enlarge a blade of the leaf indicating the increase of the leaf width (Steeves and Sussex 1989). The same occurs in two embryonic leaves (cotyledons) which are arranged in parallel to the walls of the plum stone, and in these walls. Such a description of plant organs and the designation of their characters based on the development are justified and applied in the present paper.

\section{Prunus spinosa and putative hybrids between this species and domesticated plums}

Contemporary forms of Prunus spinosa, Ps1 $\div$ Ps16, have been gathered in Roztocze (E Poland), in Lower Silesia (SW Poland), and near the Kolno hill (Fig. 5). They were compared with the fossil types collected from Kolno. The extreme individuals in the ordination space are the modern form Ps15 and the fossil type H3 (Figs. 8, 9). They determine the direction of variability 


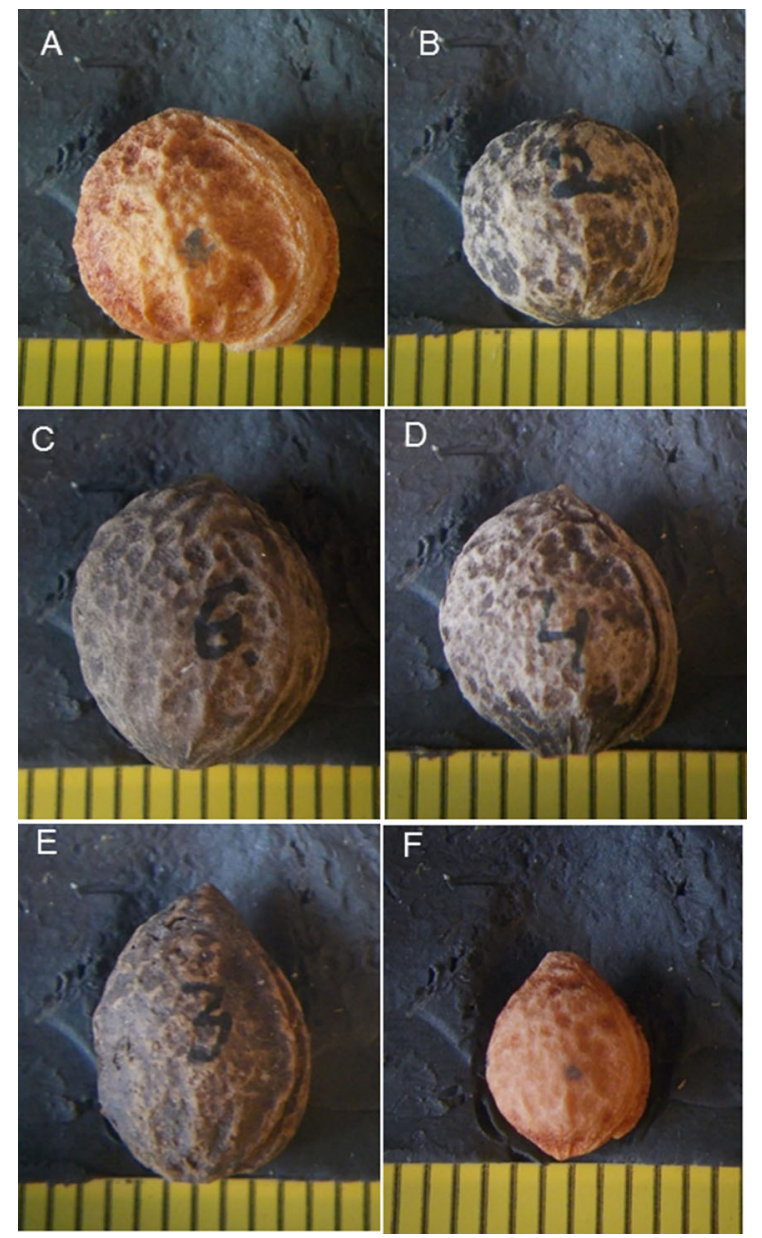

Fig. 9 Morphotypes of fossil and contemporary stones of Prunus spinosa occupying extreme positions in the minimum spanning tree (see Fig. 8). a-Ps15; b-H2; c-H6; d-H4; e$\mathrm{H} 3 ; \mathbf{f}-\mathrm{Ps} 8$. Scale in $\mathrm{mm}$

from the spheroidal to the ellipsoidal type. The cloud of OTUs in the ordination space has an ellipsoid shape stretched between the values of $x$-min, $y$-min, $z$ intermediate for Ps15 and $x$-max, $y$-max, $z$-intermediate for H3. Such an arrangement of the cloud of OTUs indicates a positive correlation of the values of OTUs for ordination axes $x / y$, but correlations between $x /$ $z$ and $y / z$ are moderate (deduced from the scattering of OTUs during rotation of the ellipsoid). It has been shown that the shape of such a cloud representing the covariance variation between the three ordination axes is characteristic for a given set of OTUs and can be used as a new complex taxonomic tool (Kosina 2004). Several extreme types are marked in Fig. 8 for fossils deposited in the layer $\mathrm{H}$, at a depth $170 \mathrm{~cm}$. OTUs encircled in Fig. 8 express intermediate morphology between domesticated plums and sloe. There is visible some asymmetry in the OTUs' arrangement in the ellipse-there are more ellipsoidal units than spherical.

A shrub of sloe growing at present at the castle hill (Fig. 2) expresses some traits typical for domesticated plums. It is approximately $6 \mathrm{~m}$ high, erect, with fruits slightly elongated with a short, thick pedicel. Its stones are asymmetrical (Fig. 10a, left). It is a putative hybrid. Some similar stones (Fig. 10a, b, right) were found in layers $\mathrm{H}$ and I $(170-180 \mathrm{~cm})$. Half of the highly ornamented stone (Fig. 10c) and a stone with a distinct crest at the stone base (Fig. 10d) express some characters of Prunus domestica subsp. syriaca. The putative sloe hybrids are always the extreme OTUs located externally compared to the pure species (Figs. 8, 11).

A cloud of mixed OTUs (wild, cultivated, putative hybrids) does not present a characteristic shape (see Fig. 11) which could be easily described by correlation and regression analyses. Plums Psy and Pi are more closely related to sloe than $P$. domestica subsp. domestica $(\mathrm{Pd})$. The putative hybrids are similar to sloe, proving the dominance of sloe, probably due to backcrosses of hybrids with sloe or its maternal influence. Stone phenotypes of some extreme OTUs from the MST diagram (Fig. 11) are presented in Fig. 12. They show two kinds of stone development, that is, variability from a small conical stone (Ps8) to a spherical one (H2).

Allometric growth occurs during the development of many fruits and it is described by curvilinear regressions (Niklas 1994). Such a regression was noted for some characters of the stone in another sloe collection. Within a set of stones close to the regression line, some specimens were distinctly outstanding and show anomalous growth caused by genetic recombination, mutation or other factors (Kosina 2005). Figures 8, 9 and 10 prove that in sloe populations one can expect a new increased variability caused by hybridisation processes and subsequent genetic recombination. This phenomenon has been evidenced by many authors in the contemporary and fossil samples. Many subspecies are distinguished within $P$. spinosa, and in addition, a hybrid form Prunus $\times$ fruticans Weihe is related to it (Hanelt 1997). Not many hybrids between sloe and domesticated plums were detected in Denmark (Nielsen and 

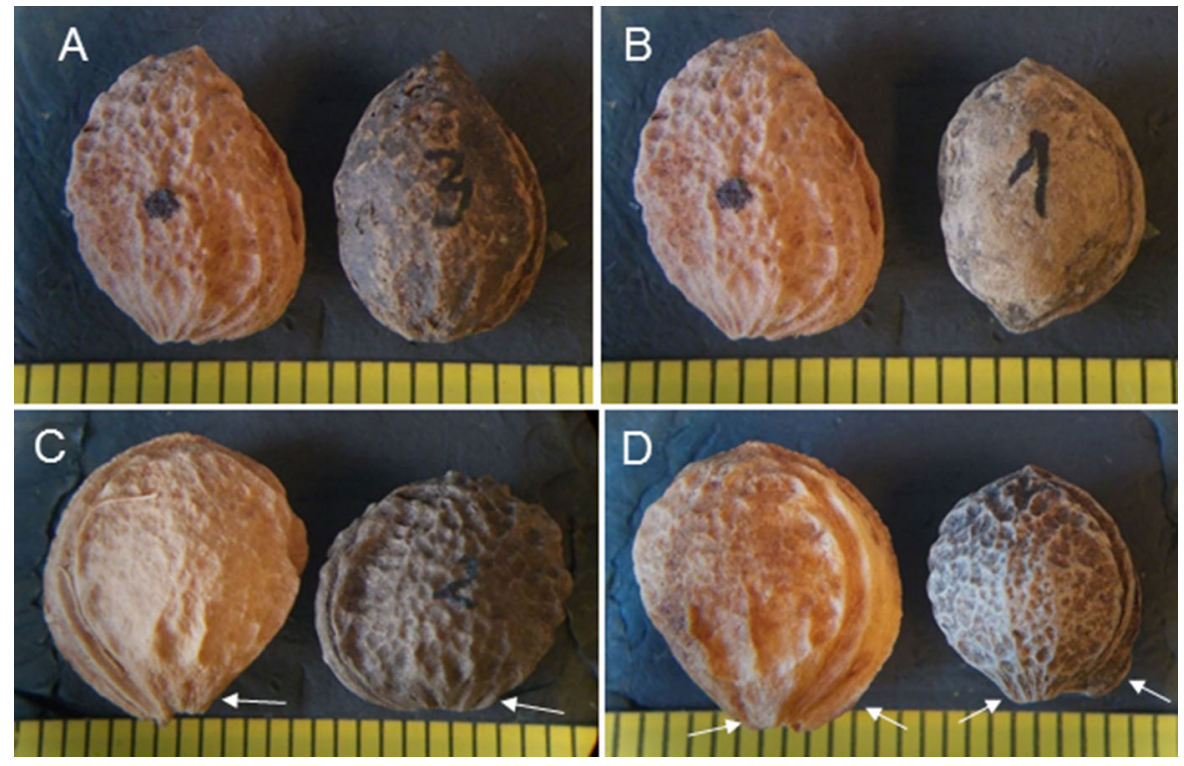

Fig. 10 A contemporary type of Prunus spinosa growing near the Kolno Castle and stones $P$. domestica subsp. syriaca (Mirabelle) compared with some fossil stones from the Kolno excavation. $\mathbf{a}$ and $\mathbf{b}$ - on the left, a contemporary stone of sloe (Ps1 in Fig. 11)) collected from a shrub growing at the castle

Olrik 2001). The authors discriminated more hybrid specimens among the OTUs of $P$. domestica subsp. insititia parent and distinctly less similar to sloe. Their data point to the bidirectional or unidirectional hybridisation with backcrosses to both parents, more frequent towards $P$. domestica. Results presented by Pollmann et al. (2005) from the Roman vicus Tasgetium prove the unidirectional process. They studied the sequences of ancient nuclear and chloroplast DNA in morphologically detected $P$. insititia/P. spinosa stones and proved that sloe is a maternal parent. The amount of stones of hybrids was estimated at $5 \%$. Hybrids are also rare in the contemporary populations of sloe in the vicinity of Wroclaw, SW Poland (Staszak 2004). Among them a stone similar to Prunus domestica subsp. syriaca (Psy) was found. The hybrids were most often found in the sloe populations which were in a pollination contact with plum gardens (R. Kosina, unpublished), and this is also confirmed by Woldring (1997/1998) and Pollmann et al. (2005). Undoubtedly, such contacts existed in the disturbed environment of the Kolno castle. The origin of the intermediate types between sloe and $P$. insititia is explained by crossing both species. The variability of intermediates is considered as a result of F2 (see Fig. 2) and fossils, H3 and I1, respectively; c and $\mathbf{d}-$ on the left, contemporary stones of Prunus domestica subsp. syriaca (Psy in Fig. 11) and fossils, L2 and K2, respectively. In c and d, the white arrows show characteristic details of the base of the stone. Scale in $\mathrm{mm}$

recombination, backcrosses and introgression (Woldring 1997/1998). Experiments involving crossing between sloe and Prunus cerasifera Ehrh. show that cross-incompatibility and cross-compatibility exists between both species (Staszak 2004). Even if the F1 hybrids are highly sterile between both species (Zohary 1992), the sterility barrier can be broken by backcrossing. This phenomenon cannot be excluded during the hybridisation of sloe with other plums. Finally, it affects the variation pattern in a population. Effective hybridisation between sloe, $P$. domestica and $P$. cerasifera is possible due to their close genetic relationships and synteny of their genomes (Shi et al. 2013; Makovics-Zsohár and Halász 2016). Thus, hybrid swarms of Prunus species, existing especially in the man-made habitats, can be considered according to Grant (1981) as syngameon, a mixture of several species and their hybridisation products of various taxonomic ranks showing limited gene exchange.

The term "syngameon" was used for the first time by J. P. Lotsy in 1917 to describe a complex unit of plant speciation (Ostenfeld 1918). Boecklen (2017) performed a computer simulation on the natural and artificial syngameons in plants and proved that their complexity correlates with the number of semi-species 


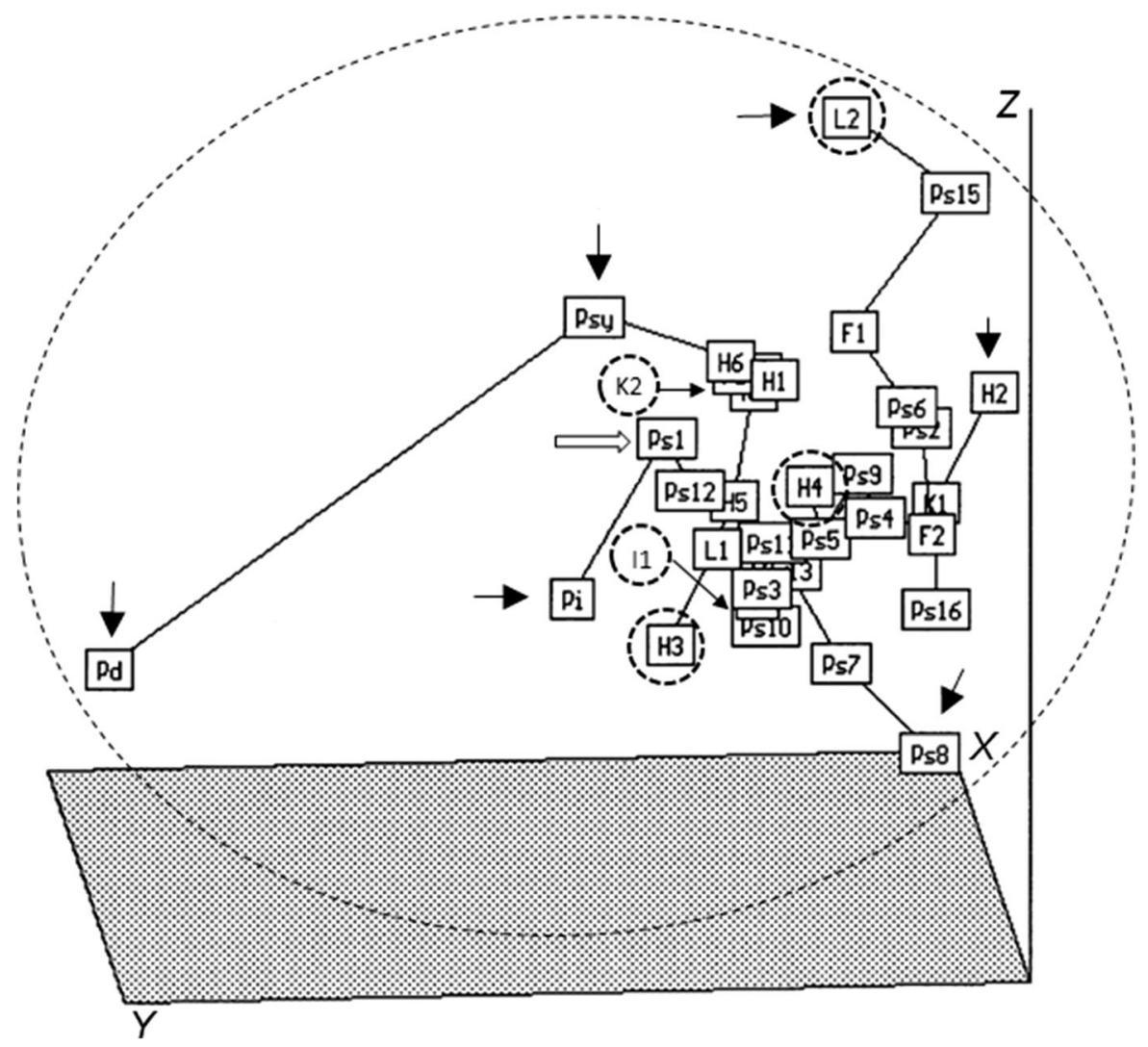

Fig. 11 Minimum spanning tree of the contemporary and fossil stones (OTUs) of Prunus spinosa and some contemporary cultivated plums (Pd, Psy, Pi) in an ordination space $(x, y$, $z$ axes). OTUs were described by four traits of stone. Extreme OTUs are marked by short arrows, Ps1 (bold arrow) is a

associated with them. He also pointed out that the differences in the genetic relationship and hybridisation propensity between the components of syngameon account for its non-random structure. Such differences have been shown to exist between the domesticated plums, sloe and P. cerasifera (Shi et al. 2013; Makovics-Zsohár and Halász 2016). The asymmetry of OTUs' arrangement shown in Fig. 8 confirms the non-random structure of the set. Analyses of meiosis in the artificial hybrids between $P$. cerasifera, P. spinosa and Prunus persica (L.) Batsch. (Salesses and Bonnet 1993) have shown that, in the case of reproductive contact, other species can also be involved in the plum syngameon. contemporary specimen showing intermediate traits between domesticated plums and sloe. Putative hybrids between $P$. spinosa and domesticated plums are encircled by a broken line. Abbreviations see in 'materials and methods'

\section{Prunus avium/P. cerasus}

Stones of Prunus avium/P. cerasus were described by four characters. Instead of the height of ventral raphae (HVR) which does not vary much in this taxon, the width of ventral raphae (WVR) was measured. Scattering of OTUs along the three ordination axes (Fig. 13) is similar to that observed for Prunus domestica s.l. (Fig. 6); however, it occurs at the lower level of character correlations (compare in Table 4). Such interrelations between characters cause a larger non-correlated inter-stone variability, and hence the cloud of OTUs is more spherical than ellipsoidal. The total variability of stone phenotypes ranges between spherical and ellipsoidal forms. The most spherical stone is the fossil N2, while the most ellipsoidal one is the contemporary Pa3 (Fig. 14). Other fossil and contemporary OTUs form a mixed group; however, 


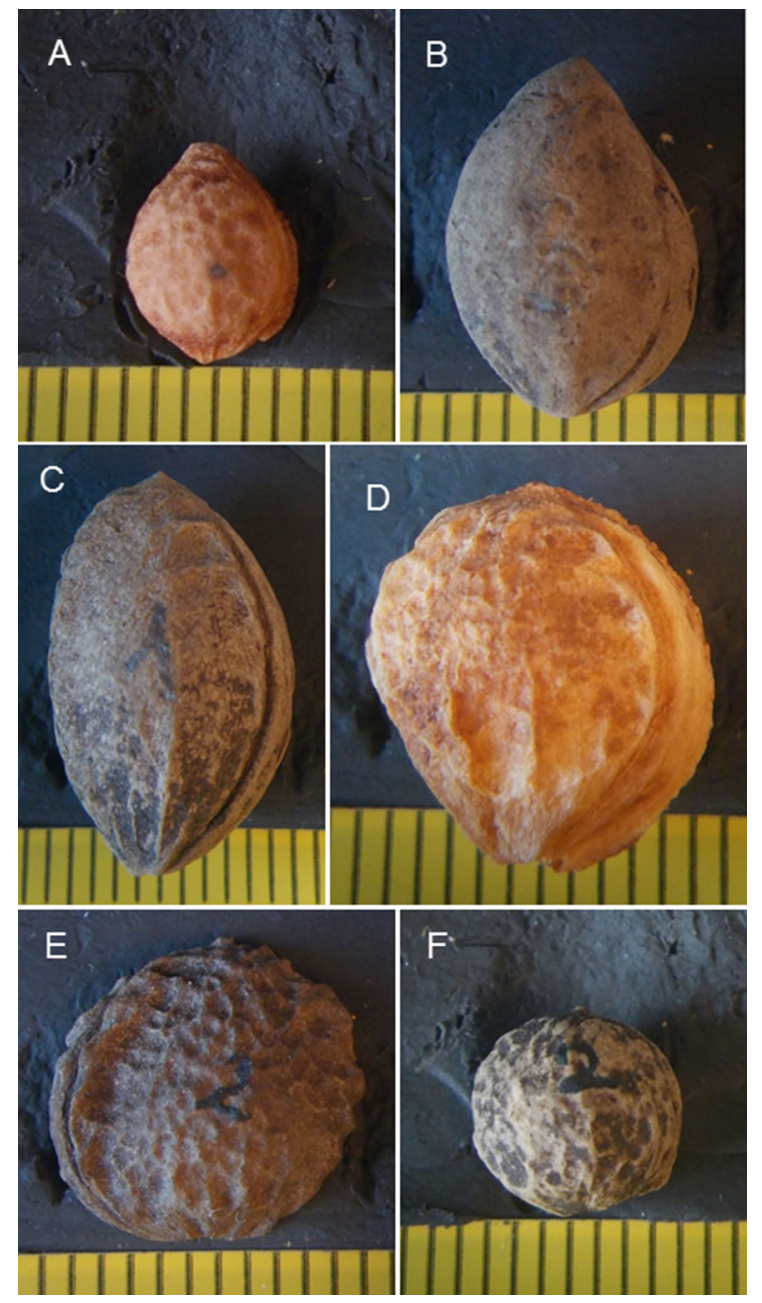

Fig. 12 Extreme stone morphotypes of contemporary (a, d) and fossil sloe and domesticated plums shown in the MST diagram (Fig. 11). a-Ps8; b-Pi (H3); c-Pd (H1); d-Psy; e-Ps (L2, hybrid?); f-Ps (H2). Scale in $\mathrm{mm}$

extreme OTUs are closer to Pa3. Such an arrangement evidences asymmetry of ellipsoid and the non-random distribution of OTUs.

Both species, Prunus avium (L.) L. and Prunus cerasus $\mathrm{L}$., were recorded in numerous excavations in mediaeval Poland (Wasylikowa et al. 1991). They were also frequent in northern Europe (Greig 1983). A distinct structural difference in the fruit attachment was found between the stones of both taxa, including mediaeval specimens; however, the distributions of variation for basic stone dimensions are overlapping (Kroll 1978), so these dimensions are useless for a comparative study. Doubts regarding the use of morphological criteria for the P. avium / P. cerasus group were also expressed by Pollmann et al. (2005). Two stone morphotypes, long versus rounded, found among $P$. avium and $P$. avium/P. cerasus were distinguished as varieties of $P$. avium (Burger et al. 2011). Such a variation is similar to that presented in Fig. 14. Studies of the reproduction pattern in P. cerasus proved that self-compatibility and self-incompatibility are expressed in this species (Hauck et al. 2002). $P$. avium is self-incompatible (Hanelt 1997), which means that hybridisation is possible between this species and P.cerasus, especially when they coexisted spatially in the Middle Ages. A close genetic relationship between these two species has also been confirmed by a molecular cytogenetic study (Schuster and Schreiber 2000) and by the conserved synteny of chloroplast and nuclear genes (Shi et al. 2013). Therefore, both species can be elements of a hybrid swarm that is also composed of genetic recombinants and backcrossing products. If Prunus fruticosa Pall. is also included (Wójcicki 1991a,b; Hanelt 1997), this swarm can be considered as a syngameon just like the $P$. domestica/insititia/spinosa/cerasifera group. In addition, for the Late Medieval period, Wasylikowa (1984) provided data on Cerasus mahaleb (L.) Mill. (a synonym of Prunus mahaleb L.) fossils collected in Poland. In Hungary, this species produces sterile hybrids (triploid) together with $P$. fruticosa (Hrotkó et al. 2020). It should be emphasised that sterility barriers can be broken by backcrossing, and so $P$. mahaleb can enlarge the size of a syngameon. Wójcicki and Marhold (1993) and Macková et al. (2017) proved that genetic relationships differ between cherries, as well as their hybridisation propensity varies, and therefore, their syngameon will have a non-random structure. Considering the trade exchange in the past centuries and the possibility of reproductive contacts with the introduced species, it can be assumed that the cherry syngameon could reach a significant size, including many species. This is also indicated by the reproductive relationships observed in various contemporary groups of sweet cherries (Schuster et al. 2013; Baek et al. 2018).

In the area of the Kolno Castle, natural fluctuations in the water level and periodic droughts favored the creation of new microniches, particularly for perennial plants that are sensitive to such changes. The products of syngameons of plums or cherries could also inhabit these niches. This environmental behavior was 


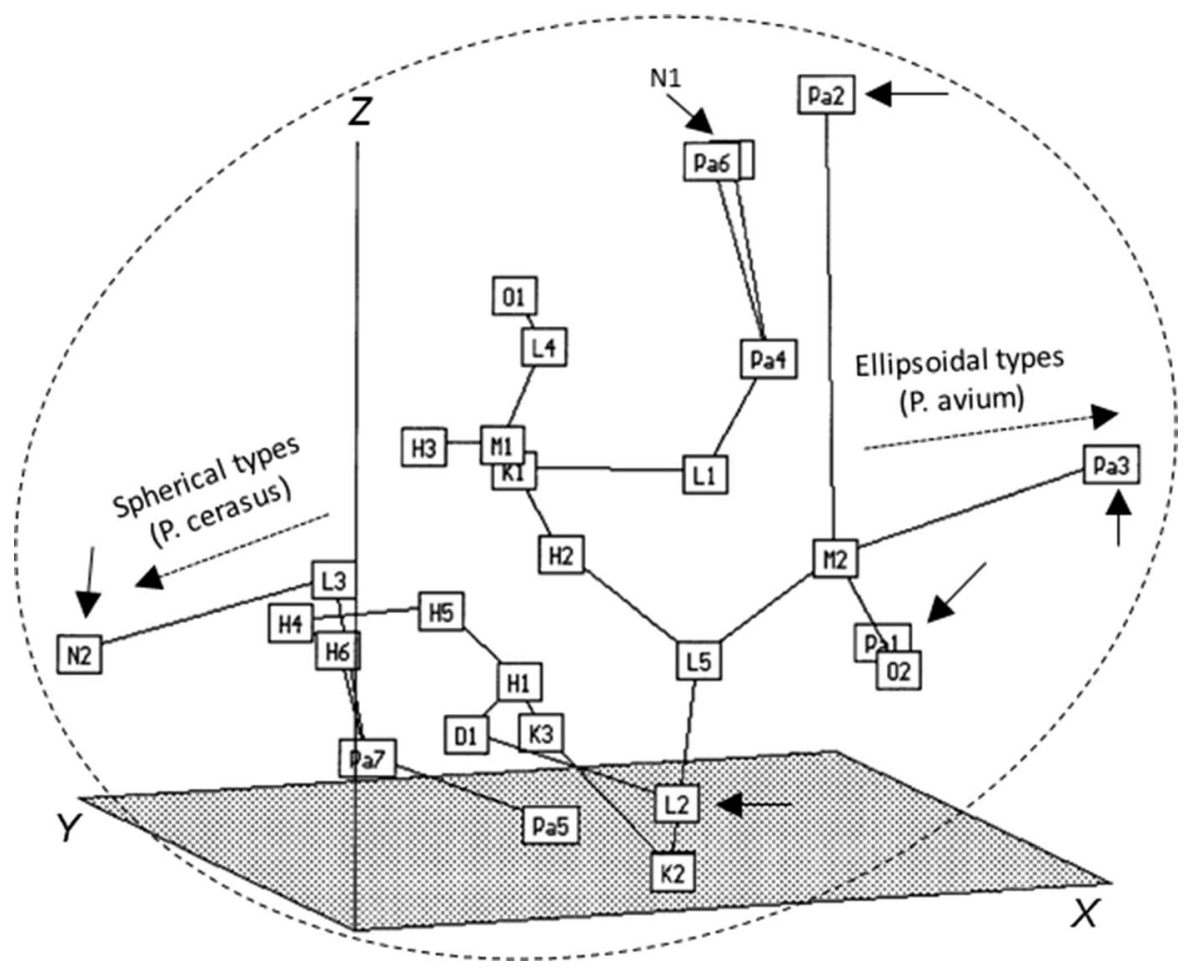

Fig. 13 Minimum spanning tree of the contemporary and fossil stones (OTUs) of Prunus avium/P. cerasus in an ordination space ( $x, y$, $z$ axes). Extreme OTUs are marked by short arrows. Abbreviations see in 'materials and methods'

enhanced by human activity, which is currently observed to be amplified (Cannon and Petit 2020).

\section{Corylus avellana-correlations of nut characters and OTUs' ordinations}

Data in Table 5 show that elongation growth of gibbosus (HG) is a significant component of such a growth of the nut as a whole. The correlations, which are lower between $\mathrm{W}$ and $\mathrm{HG}$ and distinctly higher between $\mathrm{W}$ and $\mathrm{L}$, prove that the development of the upper part of the nut is a partly independent phenomenon, probably occurring at a later stage of the nut formation. This is also corroborated by a very high correlation between $\mathrm{HG}$ and $\mathrm{HG} / \mathrm{L}$ and a lower correlation between $\mathrm{L}$ and $\mathrm{HG} / \mathrm{L}$. These interrelations between characters prove that gibbosus is a good marker to describe the gross morphology of a nut. In another study, four characters used here were perfectly scattered along the three principal component axes, both for the mesolithic and the contemporary nut samples (Kosina 1991), showing that they are not redundant.

The positive correlation between $\mathrm{L}$ and $\mathrm{HG}$ $\left(0.53^{* * *}\right)$ is expressed in the form of two extreme phenotypes of the nut, spherical, e.g. I1, and ellipsoidal, e.g. Ca17 (Fig. 15). Fossil specimens from Kolno and the contemporary nuts gathered from one large population are intermixed between extremes in the diagram. Some fossil nuts from Kolno are more outstanding (see lower values of ordination axes in Fig. 15) than any contemporary ones (Fig. 16). All OTUs create a distinct cloud arranged along the ordination axes similar to that of Prunus s.l. (see Fig. 6). The morphology of extreme types marked in Fig. 15 is presented in Fig. 16. Four specimens, I1 vs Ca18 and K4 vs Ca17 (Fig. 16 A vs B and D vs F), prove that the development of gibbosus and the upper 

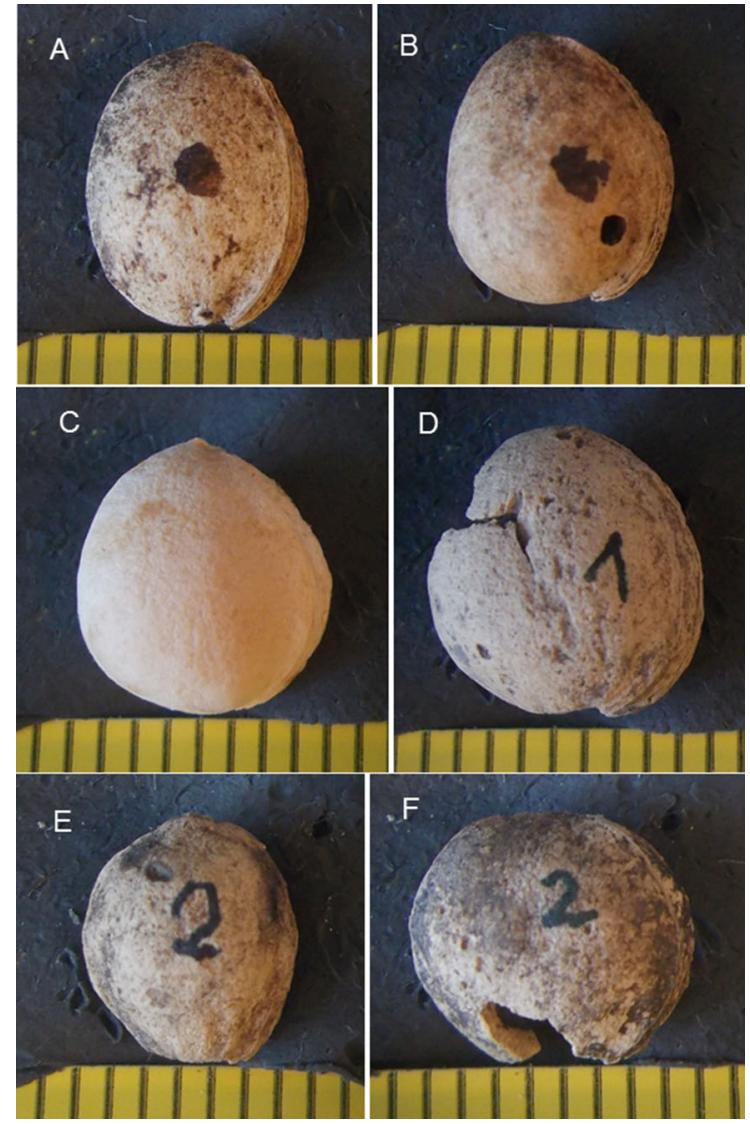

Fig. 14 Extreme phenotypes of fossil and contemporary stones of Prunus avium/P. cerasus presented in the MST diagram (Fig. 13). The range of variability is from ellipsoidal (a) to spherical (f) forms. a-Pa3 ( $P$. avium type); b-Pa2; c-Pa1; $\mathbf{d}-\mathrm{N} 1 ; \mathbf{e}-\mathrm{L} 2 ; \mathbf{f}-\mathrm{N} 2$ ( . cerasus type). Scale in $\mathrm{mm}$

Table 5 Correlations of nut characters of Corylus avellana $(n=91)$

\begin{tabular}{lllll}
\hline Characters & $\mathrm{L}$ & $\mathrm{W}$ & $\mathrm{HG}$ & $\mathrm{W} / \mathrm{L}$ \\
\hline $\mathrm{W}$ & $0.41 * * *$ & & & \\
$\mathrm{HG}$ & $0.53 * * *$ & $0.24 *$ & & \\
$\mathrm{~W} / \mathrm{L}$ & $-0.48 * * *$ & $0.58 * * *$ & $-0.25 *$ & \\
$\mathrm{HG} / \mathrm{L}$ & $0.30 * *$ & $0.14 \mathrm{~ns}$ & $0.96 * * *$ & $-0.16 \mathrm{~ns}$
\end{tabular}

*, **, ***-significance level at $\alpha=0.05,0.01,0.001$, respectively

ns-non-significant, The sample size is shown in brackets part of the nut can be partially independent, as it has been shown by the differences between character correlations. The correlation coefficients presented in Table 5 are similar to those found for another large sample $(n=246)$ of contemporary nuts, but the correlation between $\mathrm{L}$ and $\mathrm{HG} / \mathrm{L}$ is even non-significant (Kosina 1991). It corroborates the above statement on the special developmental status of gibbosus. The difference between the development of gibbosus and the upper part of the nut is particularly evident in Corylus colurna L. (R. Kosina, unpublished). A fruit scar (cicatrix carpica), including its outer sclerenchymatous rim and central gibbosus, is well preserved in fossil specimens of $C$. avellana. In Corylus heterophylla Fisch. ex Trautv., the transverse fractures of the nut shell reveal numerous canals after following the vascular bundles that run parallel to the axis (Sheng et al. 2019). This feature is also exhibited by the nuts of other species of the genus. The conductive bundles emerging from the axis branch on the gibbosus surface and between the teeth of the cicatrix carpica rim penetrate the nut shell (Kosina 1991). The traces of these bundles in the pericarp are visible as stripes on the surface of the shell. The modern trees of filbert differ in stripe numbers, and this trait was used to indicate the intraspecific variability (Ferreira et al. 2010).

Cross-incompatibility occurs in plants expressing diploid gametophytic system of self-incompatibility (Richards 1986). Cross-incompatibility also appears in diploid filbert populations (Thompson 1979) and was also noted as a mosaic of individual shrubs having nuts with kernels and shrubs with empty nuts-a mosaic of tree fertility (Kosina 1991). At present, fossil nuts from Kolno do not provide information about the above aspect. Many fragments of nuts are damaged by rodents. It is highly probable that the animals choose filled nuts as food. The presence of kernel residues in nuts preserved as a whole can be stated only after breaking them down to obtain information about the phenomenon of cross-incompatibility in the Kolno population. However, at present, it is impossible because nuts are intended for further morphometric analyses. Morphotypes of 


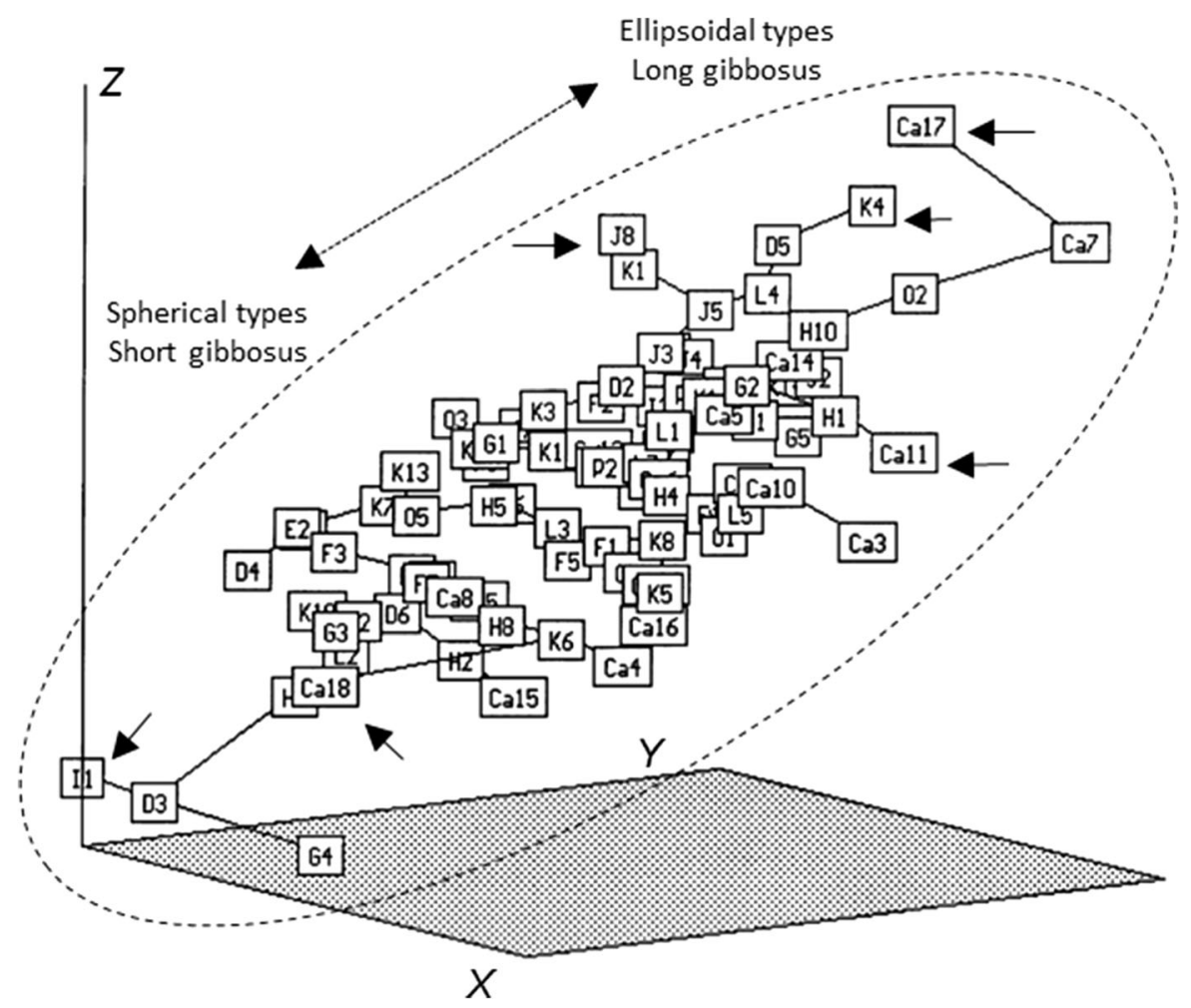

Fig. 15 Minimum spanning tree of the contemporary and fossil nuts (OTUs) of Corylus avellana in an ordination space ( $x, y, z$ axes). Extreme OTUs are marked by short arrows. Abbreviations see in 'materials and methods'

fossil nuts detected in Kolno (Figs. 15 and 16) show a large inter-shrub variability.

\section{Concluding remarks}

There are not many comparative objects in Poland for the Kolno Castle. The object is a lowland castle located in a rich network of rivers and their branches. The tested fossil material is diverse and included a random deposit in a moat, an intentional deposit in ceramic pots and a random deposit in these vessels. A small area near the castle was suitable for the cultivation of cereals and garden crops. Millet was cultivated as a polymorphic set of varieties, but a yellow-glumellae variety dominated. A set of weed species indicated that both winter and spring plants were cultivated. The correlation analysis of quantitative traits performed for plum and cherry stones and filbert nuts proved that some parts of these diaspores, the basal part and ventral raphae of the stone, as well as the gibbosus of the nut remain as partly independent components during the development of the fruit. However, the development of a Prunus stone as a whole is conservative. The ordination numerical analyses performed for macrofossils of plums and cherries showed that domesticated plums and sloe as well as wild and cultivated cherries form complexes of genetically related species and their hybridisation products. They can be considered as syngameons. Differences of the hybridisation propensity between species result a non-random structure of the syngameons. The broad variability of mediaeval filbert nuts from the vicinity of the castle is similar to the 


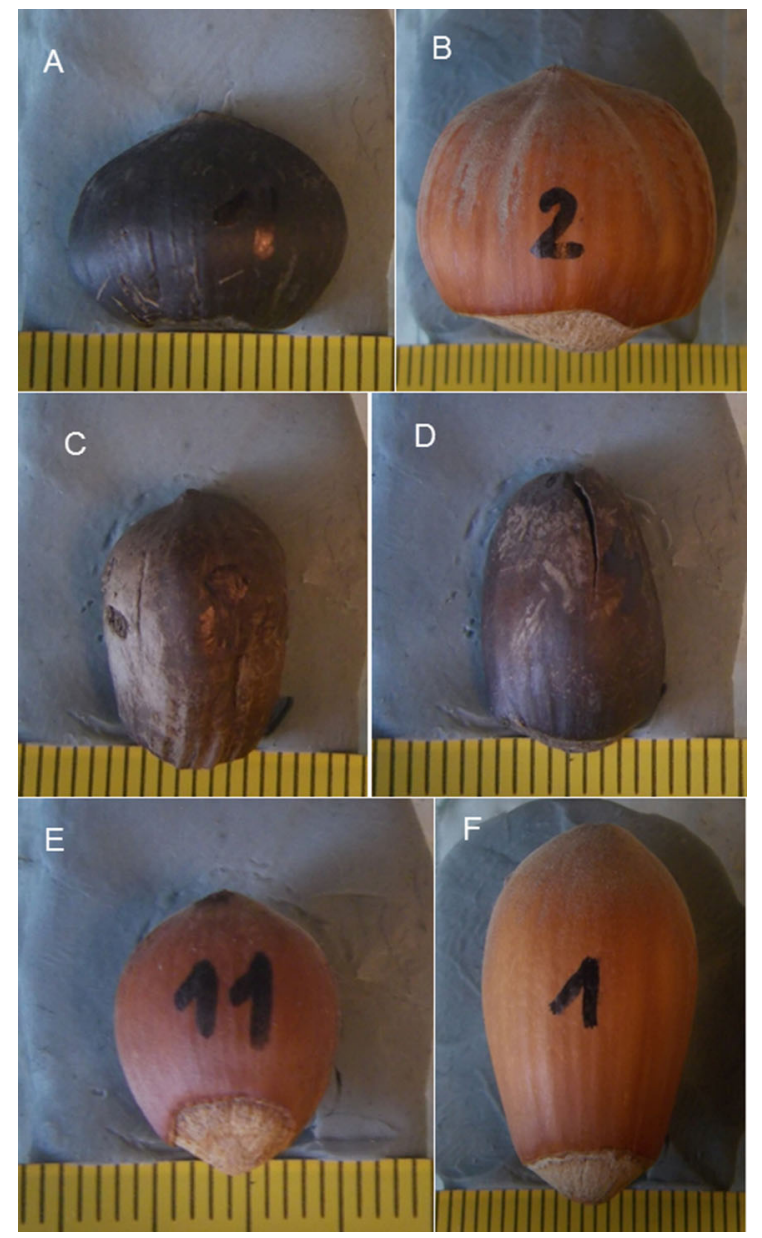

Fig. 16 Extreme phenotypes of fossil and contemporary nuts of Corylus avellana presented in the MST diagram (Fig. 15). The range of variability is from spherical (a) to ellipsoidal (f) forms. A-I1; b-Ca18; c-J8; d-K4; e-Ca11; f-Ca17. Scale in $\mathrm{mm}$

variability of one large modern population. Patterns of intrapopulational variation seen in Prunus and Corylus avellana can partly be formed due to cross-incompatibility, which gives distinctly different phenotypes. It has been shown that shapes of OTUs' clouds formed in the space of three ordination axes can be used for the additional description of the intra- or inter-specific variability.

Acknowledgements For all help and support during archeological excavations, LM thanks to: students Katarzyna Smoleń, Barbara Grabny, Martyna Kowalik, Dominika Chmura, Katarzyna Więcek, Lida Tucka, Monika Wiench, Julia Garbacz, Emilia Popek, Przemysław Tworkowski, Paweł Szadkowski, Mateusz Hermański, Wojciech Szlagura, Mateusz Makowski and Arkadiusz Panic; the landowners from Stare Kolnie: Danuta
Zając, Karol Zagórski and Zygmunt Wojtasek with family; Piotr Szafrański from the Local Government in Popielów; officers Krzysztof Spychała and Grzegorz Molenda from the Provincial Heritage Monuments Protection Office in Opole. The archaeological research was financed by grants of the Ministry of Science and Higher Education in Poland (MNiSW 2-15-1) and the Provincial Heritage Monuments Protection Office in Opole $(21 / \mathrm{K} / 2019)$.

Author contribution The section 'archaeological context' and Figs. 1, 2, 3 were elaborated and written by LM, the other sections, tables and figures were prepared and written by RK.

Data availability Fossil and contemporary research material is stored by R. Kosina (romuald.kosina@uwr.edu.pl). Others data-not applicable.

\section{Compliance with ethical standards}

Conflict of interest The authors declare that they have no conflict of interest.

Open Access This article is licensed under a Creative Commons Attribution 4.0 International License, which permits use, sharing, adaptation, distribution and reproduction in any medium or format, as long as you give appropriate credit to the original author(s) and the source, provide a link to the Creative Commons licence, and indicate if changes were made. The images or other third party material in this article are included in the article's Creative Commons licence, unless indicated otherwise in a credit line to the material. If material is not included in the article's Creative Commons licence and your intended use is not permitted by statutory regulation or exceeds the permitted use, you will need to obtain permission directly from the copyright holder. To view a copy of this licence, visit http://creativecommons.org/licenses/by/4.0/.

\section{References}

Baek S, Choi K, Kim G-B, Yu H-J, Cho A, Jang H, Kim C, Kim H-J, Chang KS, Kim J-H, Mun J-H (2018) Draft genome sequence of wild Prunus yedoensis reveals massive interspecific hybridization between sympatric flowering cherries. Genome Biology. https://doi.org/10.1186/s13059018-1497-y

Behre K-E (1978) Formenkreise von Prunus domestica L. von der Wikingerzeit bis in die frühe Neuzeit nach Fruchtsteinen aus Haithabu und Alt-Schleswig. Ber Deut Bot Ges 91:161-179

Behre K-E (1992) The history of rye cultivation in Europe. Veget Hist Archaeobot 1:141-156

Beneš J, Kaštovský J, Kočárová R, Kočár P, Kubečková K, Pokorný P, Starec P (2002) Archaeobotany of the Old Prague Town defence system, Czech Republic: archaeology, macro-remains, pollen, and diatoms. Veget Hist Archaeobot 11:107-120 
Blažková-Dubská G (2009) Finds of early modern period ceramics from cesspit B at Prague Castle. Studies in PostMedieval Archaeology 3:21-44

Boecklen WJ (2017) Topology of syngameons Ecol Evol 7:10486-10491

Burger P, Terral J-F, Ruas M-P, Ivorra S, Picq S (2011) Assessing past agrobiodiversity of Prunus avium L. (Rosaceae): a morphometric approach focussed on the stones from the archaeological site Hôtel-Dieu (16th century, Tours, France). Veget Hist Archaeobot 20:447-458

Cannon CH, Petit RJ (2020) The oak syngameon: more than the sum of its parts. New Phytol 226:978-983

Ermisch H (1876) Mittel- und Niederschlesien während der königlosen Zeit, 1440-1452. Zeitschrift des Vereins für Geschichte und Alterthum Schlesiens 13:1-72

Ferreira JJ, Garcia-González C, Tous J, Rovira M (2010) Genetic diversity revealed by morphological traits and ISSR markers in hazelnut germplasm from northern Spain. Plant Breeding 129:435-441

Grant V (1963) The origin of adaptations. Columbia University Press, New York, London

Grant V (1981) Plant speciation. Columbia University Press, New York

Greig J (1983) Plant foods in the past: a review of the evidence from northern Europe. Journal of Plant Foods 5:179-214

Hagerup O (1942) The morphology and biology of the Corylusfruit. Det Kgl. Danske Videnskabernes Selskabbiologiske Meddelelser, Bind XVII, Nr. 6, Københavni Kommission Hos Ejnar Munksgaard

Hanelt P (1997) European wild relatives of Prunus fruit crops. Bocconea 7:401-408

Hauck NR, Yamane H, Tao R, Iezzoni AF (2002) Self-compatibility and incompatibility in tetraploid sour cherry (Prunus cerasus L.). Sex Plant Reprod 15:39-46

Horvath A, Balsemin E, Barbot J-C, Christmann H, Manzano G, Reynet P, Laigret F, Mariette S (2011) Phenotypic variability and genetic structure in plum (Prunus domestica L.), cherry plum (P. cerasifera Ehrh.) and sloe (P. spinosa L.). Sci Hortic 129:283-293

Hrotkó K, Feng Y, Halász J (2020) Spontaneous hybrids of Prunus fruticosa Pall. in Hungary. Genet Resour Crop Evol 67:489-502

Kittel P, Sikora J, Antczak O, Brooks SJ, Elias S, Krąpiec M, Luoto TP, Borówka RK, Okupny D, Pawłowski D, Płóciennik M, Rzodkiewicz M, Stachowicz-Rybka R, Wacnik A (2018) The palaeoecological development of the Late Medieval moat - multiproxy research at Rozprza, Central Poland. Quatern Int 482:131-156

Klichowska M (1956) Materiał roślinny z Opola z X-XII w (Plant material from Opole from the 10th-12th c.). Materiały Wczesnośredniowieczne 4:179-209

Kosina R (1977) Wrocławskie spichrze z XI w. - przyczynek do badań nad gospodarką regionu (Wrocław granaries from the 11th c. - a contribution to research on the region's economy). Kwartalnik Historii Kultury Materialnej 2:257-267

Kosina R (1978) The cultivated and wild plants from XIth century granaries on the cathedral-island in Wroclaw. Ber Deut Bot Ges 91:121-127
Kosina R (1981) Cultivated plants, weeds, and wild plants from the early medieval granaries on Ostrów Tumski in Wroclaw. Z Archäol 15:177-190

Kosina R (1991) Remarks on the variation of fossil and contemporary nuts of Corylus avellana. In: Renfrew J (ed) New light on early farming: recent developments in palaeoethnobotany. Edinburgh University Press, Edinburgh, pp 75-91

Kosina R (1992) Mediaeval agriculture in Southwestern Poland. In: Eder-Kovar J (ed) Palaeovegetational development in Europe. Museum of Natural History, Vienna, pp 25-31

Kosina R (1995) Botanical synopsis of mediaeval Wroclaw. In: Kroll H, Pasternak R (eds) Res Archaeobotanicae. OetkerVoges-Verlag, Kiel, pp 101-116

Kosina R (2004) Wzory współzmienności osi ordynacyjnych NMMDS w opisie zmienności mikrostrukturalnej rodzajów Avena L., Brachypodium Beauv. i Bromus L. (Patterns of covariation of the NMMDS ordination axes in the description of the microstructural variability of the Avena L., Brachypodium Beauv. and Bromus L. genera). Zeszyty Problemowe Postępów Nauk Rolniczych 497:347-360

Kosina R (2005) Some aspects of leaf and stone morphometrics of Prunus spinosa L. and its two relatives. In: PrusGłowacki W (ed) Variability and evolution - new perspectives. Poznań, Wydawnictwo Naukowe UAM, pp 347-359

Kosina R, Tomaszewska P (2013) On the microstructural variability of glumellae in fossil and contemporary forms of Panicum miliaceum L. In: Kolenda J, Mierzwiński A, Moździoch S, Żygadło L (eds) Z badań nad kulturą społeczeństw pradziejowych i wczesnośredniowiecznych. Instytut Archeologii i Etnologii PAN, Wrocław, pp 627-635

Kroll H (1980) Mittelalterlich/frühneuzeitliches Steinobst aus Lübeck. Lübecker Schriften zur Archäologie und Kulturgeschichte 3:167-173

Lewicki S (1928) Proso - jego uprawa i odmiany (Millet - its cultivation and varieties). Prace Wydziału Hodowli Roślin Państwowego Instytutu Naukowego Gospodarstwa Wiejskiego w Puławach. Poradnik Gospodarstw Wiejskich 24-29:5-22

Lityńska-Zając M (2005) Chwasty w uprawach roślinnych w pradziejach i wczesnym średniowieczu (Weeds in crop cultivation in prehistory and early Middle Ages). Instytut Archeologii i Etnologii PAN, Kraków

Macková L, Vít P, Ďurišová L, Eliáš P Jr, Urfus T (2017) Hybridization success is largely limited to homoploid Prunus hybrids: a multidisciplinary approach. Plant Syst Evol 303:481-495. https://doi.org/10.1007/s00606-0161385-4

Makovics-Zsohár N, Halász J (2016) Self-incompatibility system in polyploid fruit tree species- a review. International Journal of Plant Reproductive Biology 8:1. https://doi.org/ 10.14787/ijprb.20168.1.1-0

Marek L (2014) Castle at war - archaeological records of fighting during the siege of Castle Kolno in Silesia. In: Eickhoff S, Schopper F (eds) Schlachtfeld und Massengrab - Spektren interdisziplinärer Auswertung von Orten der Gewalt. Wünsdorf, pp. 131-144 
Marek L (2017) Marcher castle on fire. Aftermath of a 15th century siege. Fasciculi Archaeologiae Historicae 30:73-81

Marek L, Paszkiewicz B (2012) Trzy monety średniowieczne z zamczyska Stare Kolnie na Dolnym Śląsku (Three medieval coins from the Stare Kolnie castle in Lower Silesia). Wiadomości Numizmatyczne 56:255-268

Niegoda J (1999) Naczynia ceramiczne (Pottery dishes). In: Buśko C, Piekalski J (eds) Ze studiów nad życiem codziennym w średniowiecznym mieście. Wratislavia Antiqua 1: $157-182$

Nielsen J, Olrik DC (2001) A morphometric analysis of Prunus spinosa, $P$. domestica ssp. insititia, and their putative hybrids in Denmark. Nord J Bot 21:349-363

Niklas KJ (1994) Plant allometry: the scaling of form and process. The University of Chicago Press, Chicago, London

Pollmann B, Jacomet S, Schlumbaum A (2005) Morphological and genetic studies of waterlogged Prunus species from the Roman vicus Tasgetium (Eschenz, Switzerland). J Archaeol Sci 32:1471-1480

Ostenfeld CH (1918) Lotsy, J.P. La quintessence de la théorie du croisement. Arch. Néerland. Sér. III, t. III, pp. 351-353, 1917. Zeitschrift für Induktive Abstammungs- und Vererbungslehre 20:46

Richards AJ (1986) Plant breeding systems. George Allen \& Unwin, London

Rohlf FJ (1994) NTSYS-pc. Numerical taxonomy and multivariate system, Exeter Software, New York

Roongsattham P, Morcillo F, Fooyontphanich K, Jantasuriyarat C, Tragoonrung S, Amblard P, Collin M, Mouille G, Verdeil J-L, Tranbarger TJ (2016) Cellular and pectin dynamics during abscission zone development and ripe fruit abscission of the monocot oil palm. Front Plant Sci. https://doi.org/10.3389/fpls.2016.00540

Rösch M (1998) The history of crops and crop weeds in southwestern Germany from the Neolithic period to modern times, as shown by archaeobotanical evidence. Veget Hist Archaeobot 7:109-125

Salesses G, Bonnet A (1993) Meiotic behaviour of hybrids between $P$. cerasifera, $P$. spinosa and $P$. persica: an approach to the peach-plum genome relationship. Cytologia 58:257-262

Schuster LM, Schreiber H (2000) Genome investigation in sour cherry. P cerasus Acta Hort 538:375-379

Schuster M, Grafe C, Hoberg E, Schütze W (2013) Interspecific hybridization in sweet and sour cherry breeding. Acta Hort 976:79-86

Sheng P, Shang X, Zhou X, Jiang H (2019) Archaeobotanical evidence of hazelnut (Corylus heterophylla, Betulaceae) exploitation in the neolithic Northern China. SAGE Open 2019:1-9. https://doi.org/10.1177/2158244019858437

Shi S, Li J, Sun J, Yu J, Zhou S (2013) Phylogeny and classification of Prunus sensu lato (Rosaceae). J Integr Plant Biol 55:1069-1079

Sommersberg FW (1729) Silesiacarum Rerum Scriptores Aliquot Adhuc Inediti, Accedunt Codicis Silesiae Diplomatici
Specimen Et Diplomatarium Bohemo-Silesiacum Vol.1, Sumtibus Michaelis Huberti, Bibliopolae Wratislaviensis, Lipsiae (Leipzig)

Speleers L, van der Valk JMA (2017) Economic plants from medieval and post-medieval Brussels (Belgium), an overview of the archaeobotanical records. Quatern Int 436:96-109

Staszak A (2004) Morfometria Prunus spinosa L. z populacji okolic Wrocławia (Morphometry of Prunus spinosa L. from the populations in the vicinity of Wrocław). MSc Dissertation, University of Wroclaw, Wroclaw

Steeves TA, Sussex IM (1989) Patterns in plant development. Cambridge University Press, Cambridge, New York

Sterling C (1964) Comparative morphology of the carpel in the Rosaceae. I Prunoideae: Prunus Am J Bot 51:36-44

Thompson MM (1979) Incompatibility alleles in Corylus avellana L. cultivars. Theor Appl Genet 55:29-33

Wasylikowa K (1981) The role of fossil weeds for the study of former agriculture. Z Archäol 15:11-23

Wasylikowa K (1984) Fossil evidence for ancient food plants in Poland. In: van Zeist W, Casparie WA (eds) Plants and ancient man. Studies in palaeoethnobotany, Balkema, Rotterdam, pp 257-266

Wasylikowa K, Cârciumaru M, Hajnalová E, Hartyányi BP, Pashkevich GA, Yanushevich ZV (1991) East-Central Europe. In: van Zeist W, Wasylikowa K, Behre K-E (eds) Progress in Old World Palaeoethnobotany. Balkema, Rotterdam, pp 207-239

Wiethold J (1995) Plant remains from town-moats and cesspits of medieval and post-medieval Kiel (Schleswig-Holstein, Germany). In: Kroll H, Pasternak R (eds) Res Archaeobotanicae. Oetker-Voges-Verlag, Kiel, pp 359-384

Willerding U (1981) Ur- und frühgeschichtliche sowie mittelalterliche Unkrautfunde in Mitteleuropa. Z Pflanzenk Pflanzen 9:65-74

Woldring H (1997/1998) On the origin of plums: a study of sloe, damson, cherry plum, domestic plums and their intermediate forms. Palaeohistoria 39/40:535-562

Wójcicki JJ (1991a) Prunus $\times$ stacei (Rosaceae), a new spontaneous threefold hybrid of $P$. fruticosa, P. cerasus and $P$. avium. Fragm Flor Geobot 35:139-142

Wójcicki JJ (1991b) Variability of Prunus fruticosa Pall. and the problem of an anthropohybridization. Veröff Geobot Inst ETH 106:266-272

Wójcicki JJ, Marhold K (1993) Variability, hybridization and distribution of Prunus fruticosa (Rosaceae) in the Czech Republic and Slovakia. Polish Bot Stud 5:9-24

Zohary D (1992) Is the European plum, Prunus domestica L., a $P$. cerasifera EHRH. $\times P$. spinosa L. allo-polyploid? Euphytica 60:75-77

Publisher's Note Springer Nature remains neutral with regard to jurisdictional claims in published maps and institutional affiliations. 